\title{
Non-invasive techniques for revealing the palette of the Romantic painter Francesco Hayez
}

\author{
LAURA RAMPAZZi*, VAlentina BRUnello, Cristina CoRTi, Elena LiSSONI
}

Dipartimento di Scienza e Alta Tecnologia, Università degli Studi dell’Insubria, via Valleggio 9, 22100 Como, Italy

Centro Speciale di Scienze e Simbolica dei Beni Culturali, Università degli Studi dell'Insubria, via Natta 14, 22100 Como, Italy

*Corresponding author (email address: laura.rampazzi@uninsubria.it)

Dipartimento di Scienza e Alta Tecnologia, Università degli Studi dell'Insubria, via Valleggio 9, 22100 Como (Italy)

\begin{abstract}
This paper describes the first systematic analysis of the palette of Francesco Hayez, one of the most outstanding artists of European Romanticism, whose painting technique has never been extensively investigated despite the plethora of artistic studies. He lived in a particular moment in the history of painting, as in the first half of the $19^{\text {th }}$ century many synthetic pigments were available, also in tin tubes, but traditional materials were still used. Sixteen paintings on canvas and on panels, created between 1823 and 1868, were analyzed in situ through non-invasive techniques (infrared reflectography and infrared reflection spectroscopy). Imaging investigation provided clues on painting technique, revealing some cases of pentimenti and underdrawings. A preliminary survey was carried out on a hundred pure pigments used up to the $19^{\text {th }}$ century and on new synthetic colours, in order to attain reference spectra for the interpretation of painting spectra. The portable infrared instrument provided insight into Hayez's painting materials, identifying barite, ivory black, lead-tin yellow, Naples yellow, ochres, Prussian blue, and white lead. The pigments were often blended, to obtain a unique fabric appearance or to attain cold shades. The results pointed to a siccative oil as a binder, mixed with white lead so that it could act as a catalyzer in polymerization reactions, and in some cases with a proteinaceous binder and resins. The preparation was made with gypsum and white lead mixed with a siccative oil. The results showed that the artist used a typical traditional palette, throughout his career, in order to lead to brilliant colors and with long-term stability. Anyway, the possible presence of cobalt blue in a few paintings suggests that Hayez had probably started testing the new colours, since the second decade of $19^{\text {th }}$ century.
\end{abstract}

Key words: Non-invasive analysis; FTIR reflectance spectroscopy; infrared reflectography; pigments characterization

\section{Graphical abstract}
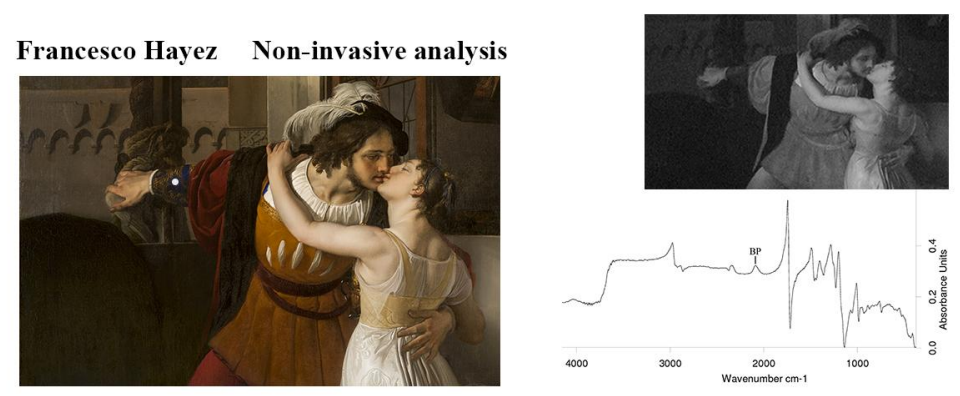


\section{Introduction}

As part of the project "The palette of Francesco Hayez", co-funded by the regional government of Lombardy (Italy) and the European Union (POR Lombardia Ob. 2 FSE 2007/2013) and managed by the University of Insubria (Italy), various museums and private art collectors in Italy have given researchers the opportunity to carry out the non-invasive analyses of Francesco Hayez paintings: Galleria Tadini (Lovere-Bergamo) Villa Carlotta (Tremezzina-Como), Villa Vigoni (Menaggio-Como), Galleria Civica d'Arte Moderna e Contemporanea (Torino), Galleria Nazionale d'Arte Moderna e Contemporanea (Roma), and Musei Civici d'Arte e di Storia (Brescia). The main aim of the project, the results of which are discussed here, was to gather information on the pigments and the binding media used by Francesco Hayez and on his painting method, through in situ infrared spectroscopy and reflectography.

Francesco Hayez (Venice, 1791 - Milan, 1882) was one of the most important Italian artists in the 19th century, and was the founder of the school of Romantic painting in Italy [Mazzocca, 2015]. In his youth, he studied at the Venice Academy of Fine Arts, and later in Rome (1809-1817) attending the atelier of the sculptor Antonio Canova, who introduced him to the most avant garde artistic circles. He held the Chair of Painting at the Brera Academy of Fine Arts in Milan until 1880 and had a great influence on later artistic periods. Hayez's paintings were admired, furthermore, for the exceptional quality of their brilliant colours and the particular technique that enabled them to be perfectly conserved. The attention that Hayez gave in choosing his painting materials is a constant aspect of his career.

Although the subjects of the historical paintings and fine portraits painted by Francesco Hayez have been widely studied by art historians, little is known about the pigments and the binding media that he used. Only a few analyses have been carried out on his palette [Bensi 2010]. The first documented analytical campaign [Di Majo 1990] concerning the painting Vespri Siciliani (1844). suggested the use of wax in an encaustic technique. Another article described the investigation of the ground layer of ten paintings through optical and electronic microscopy and Raman spectroscopy, revealing a mixture of calcite, white lead, gypsum, aluminum silicates, barite, hematite and ochres [Ferriani 2009]. Again optical and electronic microscopy investigations on L'incoronazione di Gioas (1860) led to the determination of the use of white lead, red ochre and a not clearly identified "organic green", on a ground made of white lead, oil and red ochre [Perusini 2010, Princivalle 2010]. Finally, Carini et al [Carini 2013] analysed paintings Odalisca, Betsabea al bagno, and Bacio from the Pinacoteca of Brera in Milan, by non-invasive visible reflectance and X-ray fluorescence, suggesting the presence of Prussian blue, white lead, ivory black, Naples yellow, ochres, vermilion, chrome green, ultramarine blue and rose madder. Some pentimenti and underdrawings were also revealed. To the best of our knowledge, no other documented issues have been published on Francesco Hayez.

This study presents the results of the analyses carried out on sixteen easel paintings, between 1823 to 1868 (Figure 1). Analyzing a large number of paintings regarding nearly fifty years of the painter's activity provided a unique and challenging opportunity, not only in terms of verifying possible differences at the beginning and at the end of his career, but also for the community of conservators taking care of Francesco Hayez's paintings.

The technique used in this study for decrypting the composition of the painting surface was infrared reflection spectroscopy (FTIR)-Over the last decade, portable instruments have enabled artworks to be analyzed, where sampling would be prohibited. In addition, in situ analyses of large and non-moveable objects is of primary concern, as in this case. Some of the paintings by Francesco Hayez are, in fact, large and it is unlikely that they could be moved to a laboratory. Figure 2 shows the apparatus used for analysing the L'ultimo bacio dato a Giulietta da Romeo (Villa Carlotta). In addition, the good state of conservation of the artworks make micro-sampling almost impossible. 


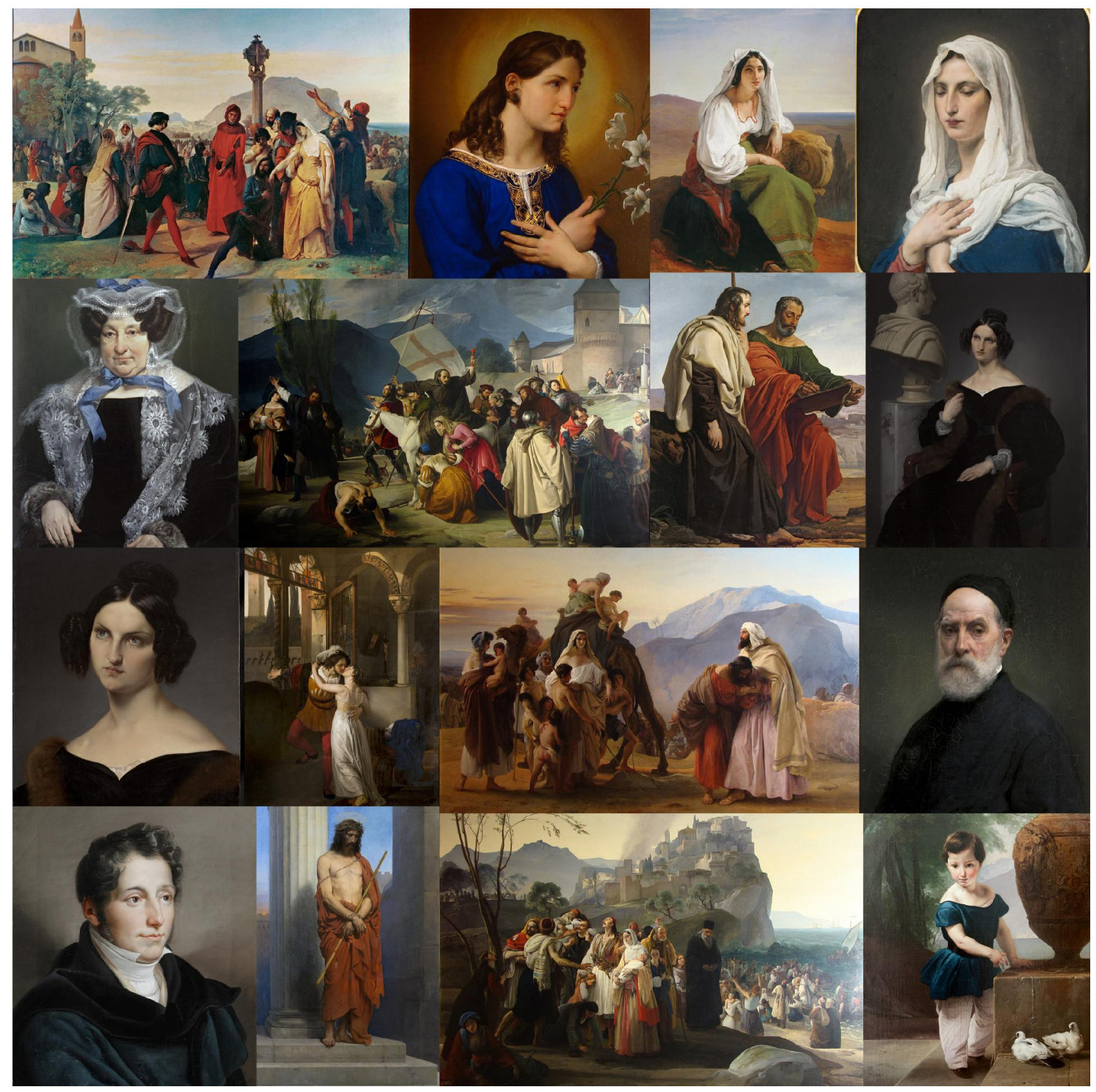

Figure 1 The easel paintings analyzed within the project "The palette of Francesco Hayez".

The contactless application requires reflection-mode analysis, which has been increasing over the last few years for painting investigations [Miliani 2007, Miliani 2012, Sessa 2014, Madariaga 2016, Rifkin 2016, Rosi 2016]. Although the technique is non-destructive, only the surface can be analyzed, thus losing information on the stratigraphy. It was in fact possible to investigate the ground layer only in one painting, which was undergoing conservation work.

Setting up the reference database was a major concern. Some of the aforementioned articles on the application of portable infrared spectroscopy report the reference spectra of pigments, however they are often not suitable for a reliable comparison and not all the peaks are specified. In most cases, pigment references are present in the literature as traditional transmission infrared spectra, not taking into account the typical distortion of the reflection acquisition mode. A new database thus need to be set up. Historical studies suggest which pigments should be considered with respect to the database, as Hayez lived through a particularly dramatic period of change in the history of art. In 1840 the first ready-made tin tubes were patented. Throughout the 19th century the evolution of the art market brought with it an expansion of the materials available for sale, aided by advances in scientific fields, which greatly expanded the range of 
pigments and dyestuffs. New synthetic pigments began to replace mineral pigments, because they enabled dazzling but also alarmingly unstable colours to be obtained. Cadmium-, chromium- and cobalt- based pigments promised brilliant green and violet nuances which had never been seen before and synthetic ultramarine and zinc white replaced expensive natural ultramarine and hazardous white lead, respectively. As a consequence, an artist's palette could comprise both natural and synthetic pigments and the painting film could also contain complex mixtures of materials.

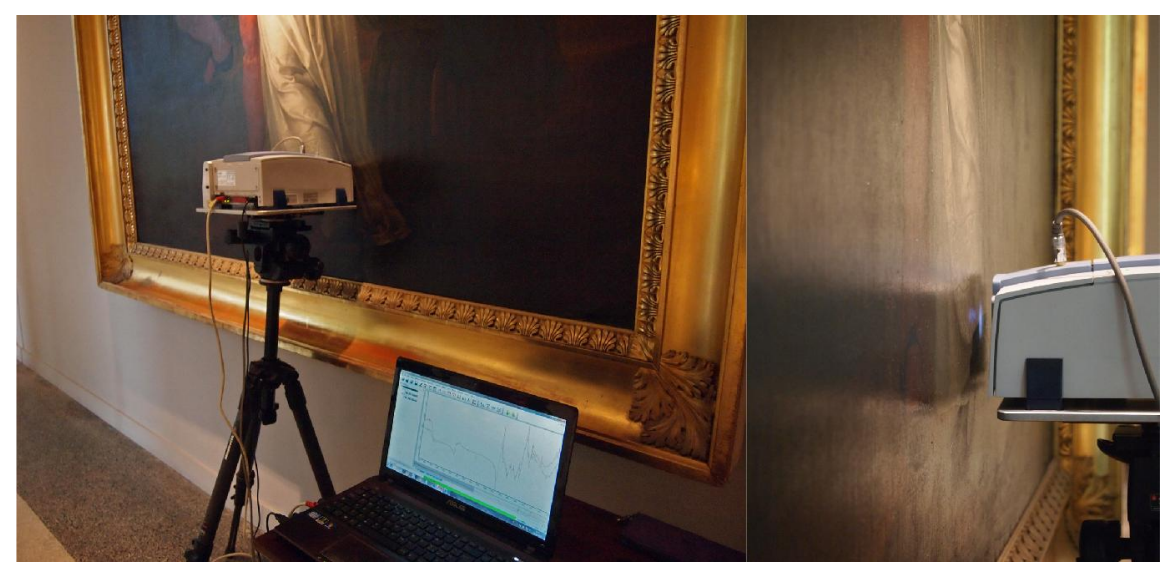

Figure 2 Photograph of the Alpha Bruker FTIR portable spectrophotometer analyzing L'ultimo bacio dato a Giulietta da Romeo (Villa Carlotta).

The FTIR investigation was combined with infrared reflectography (IRR), a well-known non-destructive image analysis technique that, combining the information on the images taken in visible light with those taken in the near infrared (850-1100 nm), clearly illustrates, where present, the changes introduced by the painter, underdrawings and pentimenti, retouches, and highlights the restoration areas [Moon 1992, Poldi 2006, Gargano 2007].

\section{Materials and methods}

The entire surface of the paintings was analyzed by infrared reflectography. Table 1 lists the year, dimensions, support, and the most representative painted areas analyzed by reflection FTIR.

\section{1 Infrared reflection analysis}

FTIR measurements were carried out with an Alpha Bruker FTIR portable spectrophotometer in reflection mode for contactless measurements and a DTGS detector. Spectra were collected between 7500 and $375 \mathrm{~cm}^{-1}$ with $4 \mathrm{~cm}^{-1}$ resolution and 200 scans. The background was periodically acquired using a flat gold mirror. The instrument was placed on a tripod in front of the measured area of about $6 \mathrm{~mm}$ in diameter (Figure 2). The optimal distance was achieved by checking the focus via the on-board camera. Subsequently, a finer tuning was achieved via software, looking for the maximum signal directly in the interferogram. The average working distance from the surface was about 1-1.5 cm. The tripod was able to reach areas up to a height of nearly 2 meters from the ground. For the large paintings, the instrument was placed on scaffolding. The spectra were processed using the pseudo-absorbance [log(1/R); $\mathrm{R}=$ reflectance] as the intensity unit.

The data were compared to a homemade database of pigments and binders references. The references were analyzed with the same parameter values. The pigments were identified in the paintings also after a comparison with the literature [Meilunas 1990, Wilson 1994, Miliani 2007, Vetter 2011, Miliani 2012, Manfredi 2015]. In the case of organic compounds, spectra of aged reference materials were considered [Meilunas 1990]. 


\begin{tabular}{|c|c|c|c|c|c|c|c|c|c|c|c|c|c|c|}
\hline \multirow{2}{*}{ Painting } & \multirow{2}{*}{$\begin{array}{c}\text { Year } \\
\text { Dimensions }\end{array}$} & \multirow{2}{*}{ Location } & \multirow{2}{*}{ Support } & \multicolumn{11}{|c|}{ Areas analyzed by reflection FTIR } \\
\hline & & & & black & blue & brown & green & grey & ochre & orange & red & rosy & white & yellow \\
\hline $\begin{array}{l}\text { L'ultimo bacio dato a Giulietta da Romeo } \\
\text { (The last Adieu of Romeo and Juliet) }\end{array}$ & $\begin{array}{c}1823 \\
291 \times 201,8 \mathrm{~cm}\end{array}$ & $\mathrm{VC}$ & $\mathrm{C}$ & $\mathrm{x}$ & $\mathrm{x}$ & $\mathrm{x}$ & & & & & $\mathrm{x}$ & & $\mathrm{x}$ & \\
\hline $\begin{array}{l}\text { L'angelo annunziatore } \\
\text { (Announcing angel) }\end{array}$ & $\begin{array}{c}1824 \\
59 \times 50 \mathrm{~cm}\end{array}$ & GCAMC & $\mathrm{P}$ & & $\mathrm{x}$ & & & & & & & $\mathrm{x}$ & & $\mathrm{x}$ \\
\hline $\begin{array}{l}\text { I due apostoli Giacomo e Filippo } \\
\text { (Apostles James and Philip) }\end{array}$ & $\begin{array}{r}1825-1827 \\
76 \times 56 \mathrm{~cm}\end{array}$ & $\mathrm{PC}$ & $\mathrm{P}$ & & & $\mathrm{x}$ & $\mathrm{x}$ & & & & & & & $\mathrm{x}$ \\
\hline $\begin{array}{l}\text { I profughi di Parga } \\
\text { (Refugees of Parga) }\end{array}$ & $\begin{array}{c}1826-1831 \\
201 \times 290 \mathrm{~cm}\end{array}$ & MCAS & $\mathrm{C}$ & $\mathrm{x}$ & $\mathrm{x}$ & & & & & & & & & \\
\hline $\begin{array}{l}\text { Pietro l'eremita } \\
\text { (Peter the Hermit) }\end{array}$ & $\begin{array}{c}1827-1829 \\
210 \times 280 \mathrm{~cm}\end{array}$ & $\mathrm{PC}$ & $\mathrm{C}$ & & $\mathrm{x}$ & & $\mathrm{x}$ & & & & $\mathrm{x}$ & & $\mathrm{x}$ & $\mathrm{x}$ \\
\hline $\begin{array}{l}\text { Ritratto di Federica Cristina Mylius Schnauss } \\
\text { (Portrait, Federica Cristina Mylius Schnauss) }\end{array}$ & $\begin{array}{c}1828 \\
74 \times 58 \mathrm{~cm}\end{array}$ & VV & $\mathrm{P}$ & $\mathrm{x}$ & $\mathrm{x}$ & $\mathrm{x}$ & $\mathrm{x}$ & & & & & & $\mathrm{x}$ & \\
\hline $\begin{array}{l}\text { Ritratto di Giulio Mylius (attributed to) } \\
\text { (Portrait, Giulio Mylius) }\end{array}$ & $\begin{array}{c}1830-1835 \\
51,5 \times 42 \mathrm{~cm}\end{array}$ & VV & $\mathrm{C}$ & $\mathrm{x}$ & $\mathrm{x}$ & & & & & & $\mathrm{x}$ & $\mathrm{x}$ & $\mathrm{x}$ & \\
\hline $\begin{array}{l}\text { Ritratto di Luigia Vitali Mylius Vigoni } \\
\text { (Portrait, Luigia Vitali Mylius Vigoni) }\end{array}$ & $\begin{array}{c}1832 \\
131 \times 100 \mathrm{~cm}\end{array}$ & VV & $\mathrm{P}$ & $\mathrm{x}$ & & $\mathrm{x}$ & & $\mathrm{x}$ & & & & $\mathrm{x}$ & $\mathrm{x}$ & \\
\hline $\begin{array}{l}\text { Ritratto di Luigia Vitali Mylius Vigoni (d'après) } \\
\text { (Portrait, Luigia Vitali Mylius Vigoni) }\end{array}$ & $\begin{array}{c}1832-1835 \\
50,5 \times 41,7 \mathrm{~cm}\end{array}$ & VV & $\mathrm{P}$ & $\mathrm{x}$ & & & & $\mathrm{x}$ & & & & $\mathrm{x}$ & & \\
\hline
\end{tabular}




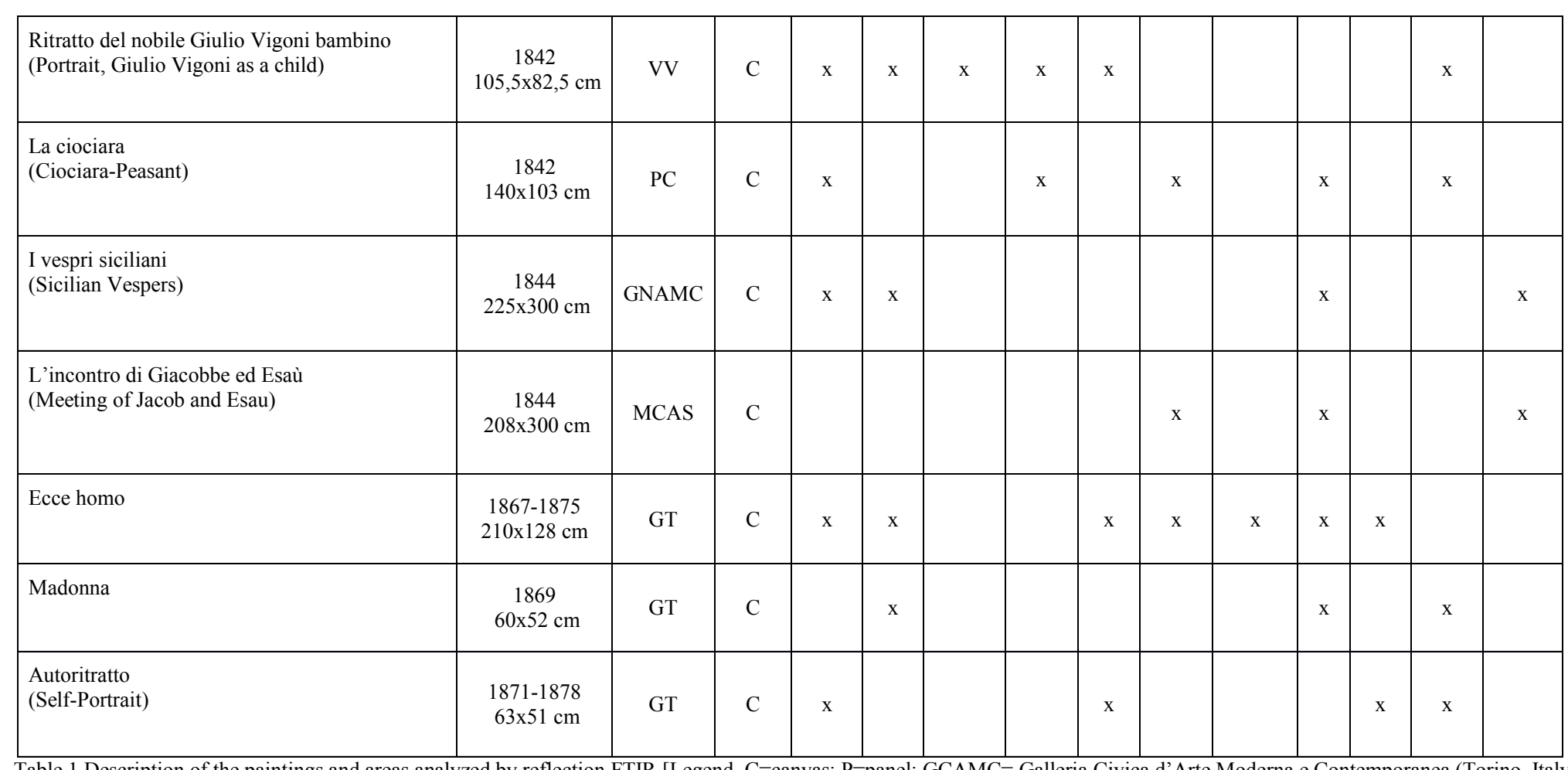

Table 1 Description of the paintings and areas analyzed by reflection FTIR [Legend. C=canvas; $\mathrm{P}=$ panel; GCAMC= Galleria Civica d'Arte Moderna e Contemporanea (Torino, Italy); GNAMC=Galleria Nazionale d'Arte

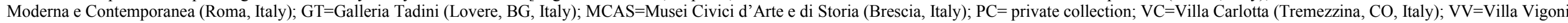
(Menaggio, CO, Italy)] 


\subsection{Infrared reflectography}

Infrared reflectography was carried out in situ with a camera (Sony DSC-H9) equipped with Carl Zeiss Vario-Tessar camera lens and Super HAD CCD (Charge Coupled Device) array sensor, operating at wavelengths between 850 and $1100 \mathrm{~nm}$ in the near infrared (NIR). The CCD has 8.1 Megapixel and $3264 \mathrm{x} 2448$ pixels for each photogram. The camera was equipped with a high-pass filter $850 \mathrm{~nm}$. The lamp used for the lighting was a $1000 \mathrm{~W}$ halogen type (QL1000W model).

\subsection{The reference palette}

The market of painting materials was investigated, looking for the purest pigments and the formulations prepared in accordance with old treatises on the art of painting. The presence of impurities or fillers could in fact make a comparison difficult. The database atse includes a hundred pigments used up to the 19th century, new synthetic colours and the traditional binding media used at the time, such as siccative oils (linseed, walnut and poppy seeds oils), glues, egg, and natural resins.

The powders of pigments used as references were crushed in an agate mortar, obtaining homogeneous fine particles. The palette mock-ups were prepared by spreading the pigments (Zecchi, Firenze, Italy; Kremer Pigmente GmbH, Aichstetten, Germany; Sigma Aldrich, Saint Louis, Missouri, United States) in two ways: using a spatula on rough glass slides and on cotton paper slides in a mixture with pre-polymerized linseed oil. Powders of pure pigments were also transferred to the pellet die and pressed into a transparent pellet and analyzed.

\section{Results and discussion}

\section{Infrared Reflection Analysis}

Infrared analyses were carried out on areas representative of the palette of each painting. The pigments identified in the paintings are listed in Table 2.

The sharp and intense absorbances occurring around 2915 and $2850 \mathrm{~cm}^{-1}$, which are ascribed to C-H stretching modes, coupled to their combination bands at 4340-30 and $4260 \mathrm{~cm}^{-1}$, suggested the presence of an organic substance, possibly the painting binder [Meilunas 1990, Rosi 2016]. The derivative-shaped band with inflection around $1750 \mathrm{~cm}^{-1}$ is characteristic of the carbonyl $\mathrm{C}=\mathrm{O}$ asymmetric stretching (Figure 3). The pattern of bands, which was observed in all the spectra, is characteristic of a lipidic compound, especially a siccative oil. The doublet at $4340-30 \mathrm{~cm}^{-1}$ is diagnostic, in particular [Rosi 2016]. The spectra of the most popular siccative oils (linseed, walnut, poppy seed oil) did not present significant differences, except for the range 4000-4600 $\mathrm{cm}^{-1}$, as shown by Vagnini et al. [Vagnini 2009]. The intensity ratios of bands around $4340-30$ and $4260 \mathrm{~cm}^{-1}$ with respect to the combination band of $\mathrm{C}=\mathrm{O}$ and $\mathrm{CH}_{2}$ stretching observed around $4700 \mathrm{~cm}^{-1}$ seem to point to the presence of linseed oil. 


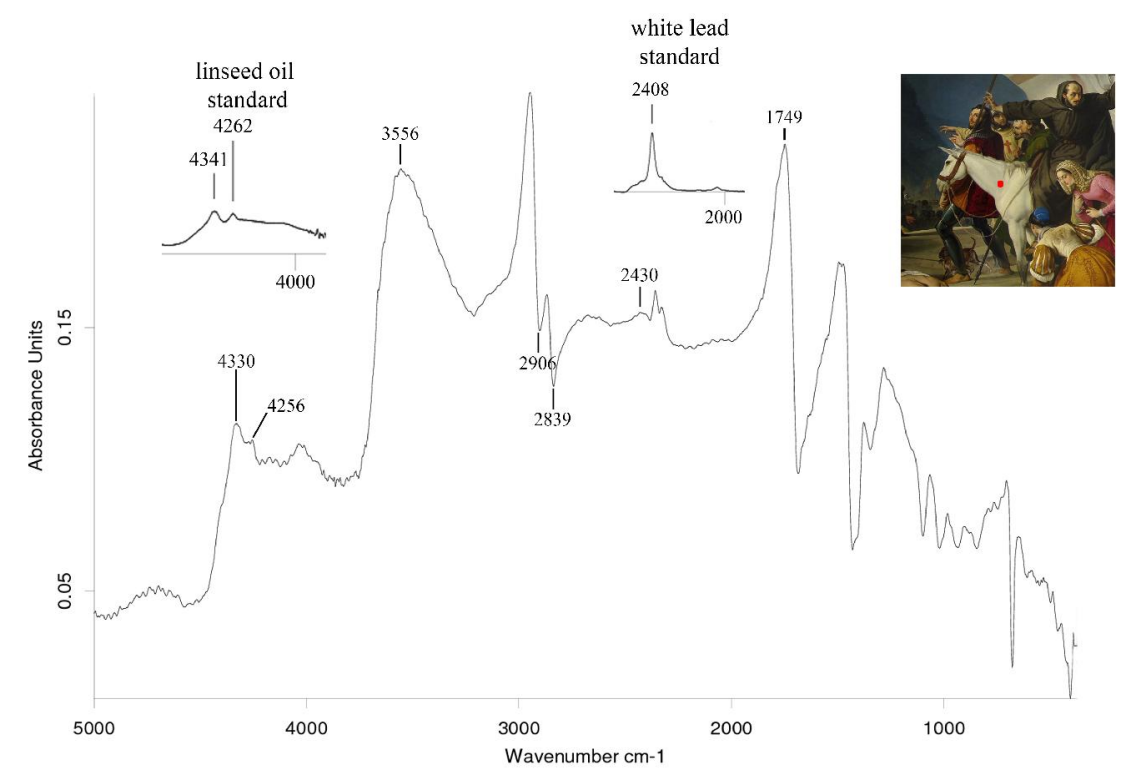

Figure 3 FTIR spectrum in pseudo-absorbance of a white area of Pietro l'Eremita (private collection), showing the features of a siccative oil (4330, $\left.4256,2906,2839,1749 \mathrm{~cm}^{-1}\right)$ and of white lead $\left(3556,2430\right.$ and $\left.1749 \mathrm{~cm}^{-1}\right)$. The peculiar peaks of white lead and linseed oil references are also shown.

The pattern of spectral bands around 6907, 4300, 3540, and $2428-2410 \mathrm{~cm}^{-1}$ is present in all the spectra too. The absorbance around 6907 and $3540 \mathrm{~cm}^{-1}$ may be assigned to the stretching mode of the O-H group, the former being an overtone mode [Vetter 2011, Vagnini 2009]. The combination bands of O-H and carbonate anion at 4300 and 2428$2410 \mathrm{~cm}^{-1}$ are confirmatory signals of the presence of white lead, i.e. basic lead carbonate $2 \mathrm{PbCO}_{3} \mathrm{~Pb}(\mathrm{OH})_{2}[\mathrm{Miliani}$ 2012]. When white lead is present, it is known that the identification of the binder could be misled [Miliani 2012]. For example, the pigment shows a peak around $1740 \mathrm{~cm}^{-1}\left(\mathrm{CO}_{3}{ }^{2-}\right.$ stretching mode), but an overlapping with esters vibrations of oil triglycerides occurs and the peak cannot be considered diagnostic [Miliani 2012]. In our case, the presence of the combination bands at $4340-30$ and $4260 \mathrm{~cm}^{-1}$ definitely points to a lipidic binder, as in the near infrared range the pigment overlapping is limited [Rosi 2016].

Figure 3 shows the signals of white lead observed in Pietro l'Eremita. The pigment traditionally occurs in nature as the mineral cerussite, however Pliny and Vitruvius describe the preparation from vinegar and metallic lead [Gettens 1966]. It is considered as by far the most important pigment in Europe, and was used from antiquity up to the birth of zinc white and titanium white. The association with white lead due to the catalyzing role in the polymerization reaction of siccative oils, especially linseed oil-with the formation of lead soaps, which keep oil films dry and hard-supports our hypothesis about the binding medium, as well as the prevalence of linseed oil in 19th century artists' palettes [Gettens 1966, Carlyle 1999, Bensi 2010, de Viguerie 2016 and references therein].

In some of the paintings the signals of siccative oil co-existed with bands around 2980 and $2940 \mathrm{~cm}-1$. These values suggest the presence of resinous varnishes [Derrick 1999]. Various types of natural resins exhibit in fact strong C-H stretching vibrations at higher wavenumbers than those observed in siccative oils, due possibly to the cyclic ring structure. 


\begin{tabular}{|c|c|c|c|c|c|c|c|c|c|}
\hline \multirow{2}{*}{ Painting } & \multicolumn{9}{|c|}{ Pigments identified by reflection FTIR } \\
\hline & Barite & $\begin{array}{l}\text { Cobalt } \\
\text { blue }\end{array}$ & $\begin{array}{l}\text { Ivory } \\
\text { black }\end{array}$ & $\begin{array}{l}\text { Lead-tin } \\
\text { yellow }\end{array}$ & $\begin{array}{l}\text { Naples } \\
\text { yellow }\end{array}$ & $\begin{array}{l}\text { Natural } \\
\text { ultramarine }\end{array}$ & Ochres & $\begin{array}{l}\text { Prussian } \\
\text { blue }\end{array}$ & $\begin{array}{l}\text { White } \\
\text { lead }\end{array}$ \\
\hline $\begin{array}{l}\text { L'ultimo bacio dato a Giulietta da Romeo } \\
\text { (The last Adieu of Romeo and Juliet) }\end{array}$ & & & $\mathrm{x}$ & & & & & $\mathrm{x}$ & $\mathrm{x}$ \\
\hline $\begin{array}{l}\text { L'angelo annunziatore } \\
\text { (Announcing angel) }\end{array}$ & & & & & & $\mathrm{x}$ & $\mathrm{x}$ & & $\mathrm{x}$ \\
\hline $\begin{array}{l}\text { I due apostoli Giacomo e Filippo } \\
\text { (Apostles James and Philip) }\end{array}$ & & & $\mathrm{x}$ & & $\mathrm{x}$ & & & $\mathrm{x}$ & $\mathrm{x}$ \\
\hline $\begin{array}{l}\text { I profughi di Parga } \\
\text { (Refugees of Parga) }\end{array}$ & & & $\mathrm{x}$ & & & & & & $\mathrm{x}$ \\
\hline $\begin{array}{l}\text { Pietro l'Eremita } \\
\text { (Peter the Hermit) }\end{array}$ & & $\mathrm{x}$ & $\mathrm{x}$ & $\mathrm{x}$ & $\mathrm{x}$ & & & $\mathrm{x}$ & $\mathrm{x}$ \\
\hline $\begin{array}{l}\text { Ritratto di Federica Cristina Mylius Schnauss } \\
\text { (Portrait, Federica Cristina Mylius Schnauss) }\end{array}$ & & $\mathrm{x}$ & $x$ & & & & & $x$ & $\mathrm{x}$ \\
\hline $\begin{array}{l}\text { Ritratto di Giulio Mylius (attributed to) } \\
\text { (Portrait, Giulio Mylius) }\end{array}$ & & & $\mathrm{x}$ & & & & $\mathrm{x}$ & $\mathrm{x}$ & $\mathrm{x}$ \\
\hline $\begin{array}{l}\text { Ritratto di Luigia Vitali Mylius Vigoni } \\
\text { (Portrait, Luigia Vitali Mylius Vigoni) }\end{array}$ & & & $\mathrm{x}$ & & & & $\mathrm{x}$ & $\mathrm{x}$ & $\mathrm{x}$ \\
\hline $\begin{array}{l}\text { Ritratto di Luigia Vitali Mylius Vigoni } \\
\text { (d'après) } \\
\text { (Portrait, Luigia Vitali Mylius Vigoni) }\end{array}$ & & & $\mathrm{x}$ & & & & $\mathrm{x}$ & & $\mathrm{x}$ \\
\hline $\begin{array}{l}\text { Ritratto del nobile Giulio Vigoni bambino } \\
\text { (Portrait, Giulio Vigoni as a child) }\end{array}$ & $\mathrm{x}$ & & $\mathrm{x}$ & & & & $\mathrm{x}$ & $\mathrm{x}$ & $\mathrm{x}$ \\
\hline $\begin{array}{l}\text { La ciociara } \\
\text { (Ciociara-Peasant) }\end{array}$ & $\mathrm{x}$ & & $\mathrm{x}$ & & $\mathrm{x}$ & & $\mathrm{x}$ & $\mathrm{x}$ & $\mathrm{x}$ \\
\hline $\begin{array}{l}\text { I Vespri Siciliani } \\
\text { (Sicilian Vespers) }\end{array}$ & $x$ & $\mathrm{x}$ & $\mathrm{x}$ & & & & $\mathrm{x}$ & $\mathrm{x}$ & $\mathrm{x}$ \\
\hline $\begin{array}{l}\text { L'incontro di Giacobbe ed Esaù } \\
\text { (Meeting of Jacob and Esau) }\end{array}$ & $\mathrm{x}$ & & $\mathrm{x}$ & & & & $\mathrm{x}$ & & $\mathrm{x}$ \\
\hline Ecce Homo & $\mathrm{x}$ & & $\mathrm{x}$ & & $\mathrm{x}$ & $\mathrm{x}$ & $\mathrm{x}$ & & $\mathrm{x}$ \\
\hline Madonna & & & & & & & $\mathrm{x}$ & $\mathrm{x}$ & $\mathrm{x}$ \\
\hline $\begin{array}{l}\text { Autoritratto } \\
\text { (Self-Portrait) }\end{array}$ & & & $\mathrm{x}$ & & & & $\mathrm{x}$ & $\mathrm{x}$ & $\mathrm{x}$ \\
\hline
\end{tabular}

Table 2. Description of the pigments identified in each painting.

The fingerprint region is characteristic for each particular resin and was used to distinguish between them, however the overlapping of the bands of the other components meant that a reliable classification was not possible. The signals of the resins did not hinder the signals of the siccative oil and pigments on the surface, suggesting that they were probably applied as a glazing, namely mixed with the binder or as very thin superimposed layers (Figure 4). Only in three paintings did the amide I C-O stretching band around $1660 \mathrm{~cm}^{-1}$ suggest the presence of a proteinaceous compound, mixed with the siccative oil [Meilunas 1990]. A more precise identification of either egg or glue was not possible due to the overlap of intense linseed oil and white lead bands. 


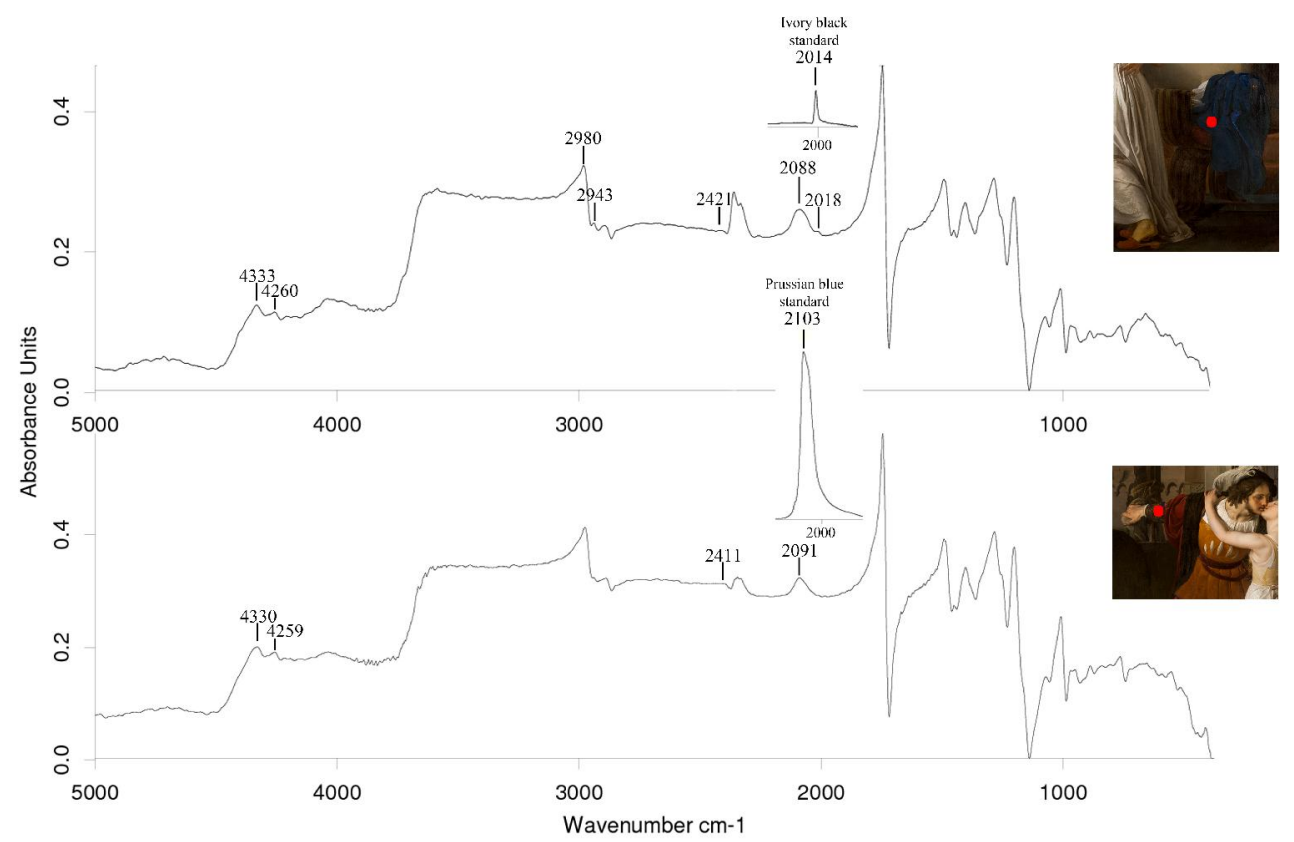

Figure 4 FTIR spectra in pseudo-absorbance of two distinct blue areas of L'ultimo bacio dato a Giulietta da Romeo (Villa Carlotta), showing the peculiar peaks of Prussian blue $\left(2088 \mathrm{~cm}^{-1}\right)$ and ivory black $\left(2018 \mathrm{~cm}^{-1}\right)$ (top) and Prussian blue $\left(2091 \mathrm{~cm}^{-1}\right)$ (bottom). The peculiar peaks of Prussian blue and ivory black references are also shown. The spectrum at the top shows the peculiar peaks of a siccative oil $\left(4333,4260 \mathrm{~cm}^{-1}\right)$, white lead $\left(2421 \mathrm{~cm}^{-1}\right)$ and a resin $\left(2980,2943 \mathrm{~cm}^{-1}\right)$, while spectrum at the bottom shows the peculiar peaks of a siccative oil $\left(4330,4259 \mathrm{~cm}^{-1}\right)$ and white lead $\left(2411 \mathrm{~cm}^{-1}\right)$.

Black pigments. Black was commonly used by Hayez in the paintings investigated here. A sharp feature around 2010 $\mathrm{cm}^{-1}$, which is present in most of the black areas, easily identified ivory black, known also as bone black [Miliani 2007]. The attribution of the band, which is absent in black pigments of a different origin, is not sure. According to some authors it is characteristic of isocy-anate, thiocyanate, and isothyocianate groups related to degradation products of proteins [Tomasini 2012]; elsewhere the band is assigned to cyanamide formed during heating of the apatite contained in bones [Ren 2014, Van Strydonck 2015]. The band is also associated with calcium phosphate $\mathrm{Ca}_{3}\left(\mathrm{PO}_{4}\right)_{2}$ (stretching of ion phosphate) [Miliani 2007]. When the signal is lacking, we proposed the use of black pigment of non-animal origin, such as vine black, charcoal black or bitumen. These compounds are in fact invisible in the operating range of the instrument. Figure 5 compares two black areas of the same painting (Ritratto di Giulio Mylius): only in one case was ivory black found. In the spectra of the black areas, the signals of white lead are less intense, probably because it is present in smaller quantities.

Blue pigments. Hayez's paintings present various blue areas, ranging from dark to light shades. The spectra recorded in the dark areas presented a signal around $2090 \mathrm{~cm}^{-1}$, which is mostly sharp and strong. The peak (Figure 4) led to an unambiguous identification of the triple bond C-N stretching, peculiar of Prussian blue $\left(\mathrm{Fe}_{4}\left(\mathrm{Fe}[\mathrm{CN}]_{6}\right)_{3}\right)$ [Vetter 2011]. Invented by chance in 1704 by Diesbach, Prussian blue was considered as the first modern pigment. Sometimes it cooccurred with a sharp feature around $2010 \mathrm{~cm}^{-1}$, meaning that it was mixed with ivory black, as in the case presented in Figure 4. In the work Madonna, Prussian blue was determined in the dark background, just over the right shoulder. In this case it is unlikely that dark and blue pigments were mixed intentionally given that the infrared reflectography pictures taken in the same area revealed a pentimento. Hayez redefined the volumes of the figure, covering the blue mantel with a dark pigment, possibly a black pigment of non-animal origin (Figure 6), but signals of Prussian blue were still recorded by infrared spectroscopy. 


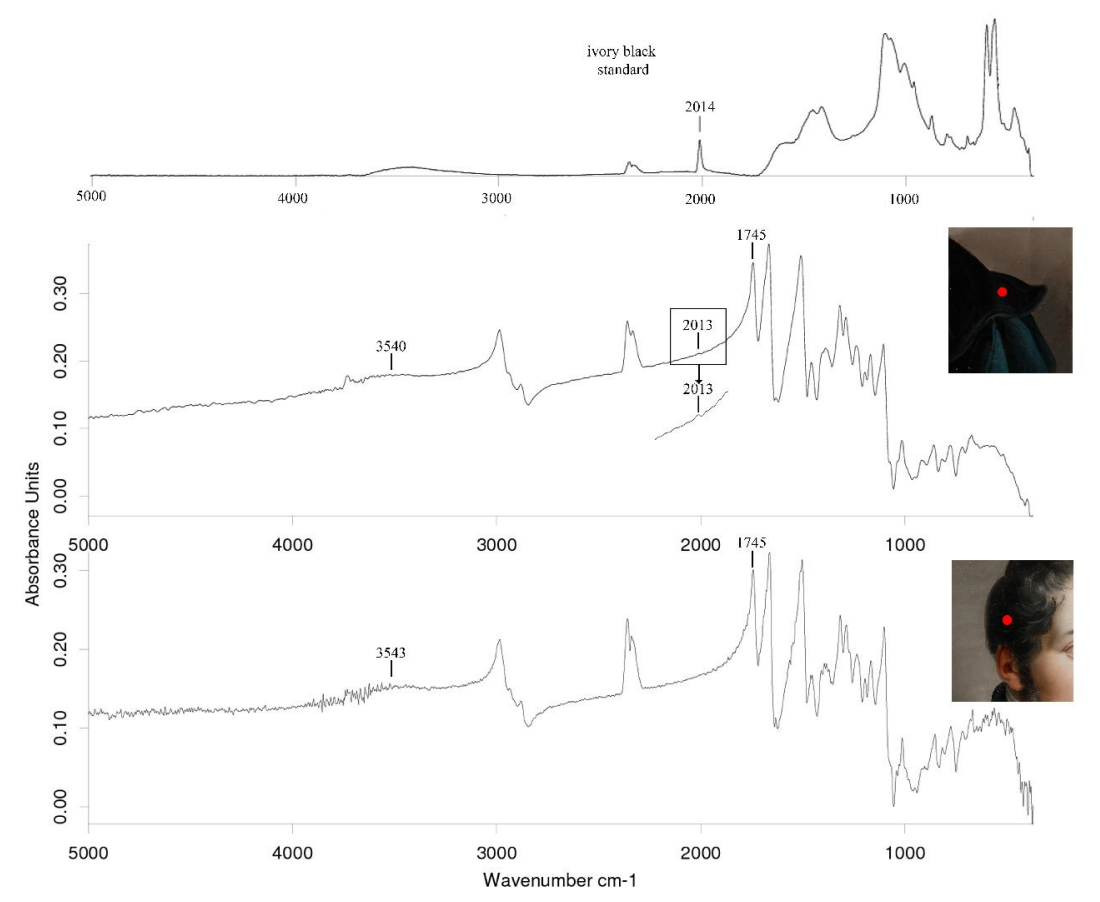

Figure 5 FTIR spectra in pseudo-absorbance of two black areas of Ritratto di Giulio Mylius (Villa Vigoni), suggesting in one case (the spectrum in the middle) the presence of ivory black $\left(2013 \mathrm{~cm}^{-1}\right)$, white lead $\left(3540 \mathrm{~cm}^{-1}\right)$ and a siccative oil $\left(1745 \mathrm{~cm}^{-1}\right)$. The characteristic peak of ivory black reference is also shown (top). In the spectrum at the bottom, the signal of ivory black is not present, so it could be hypothesized that a non-animal black was used. In this spectrum, white lead $\left(3543 \mathrm{~cm}^{-1}\right)$ and siccative oil $\left(1745 \mathrm{~cm}^{-1}\right)$ characteristic peaks can be seen.
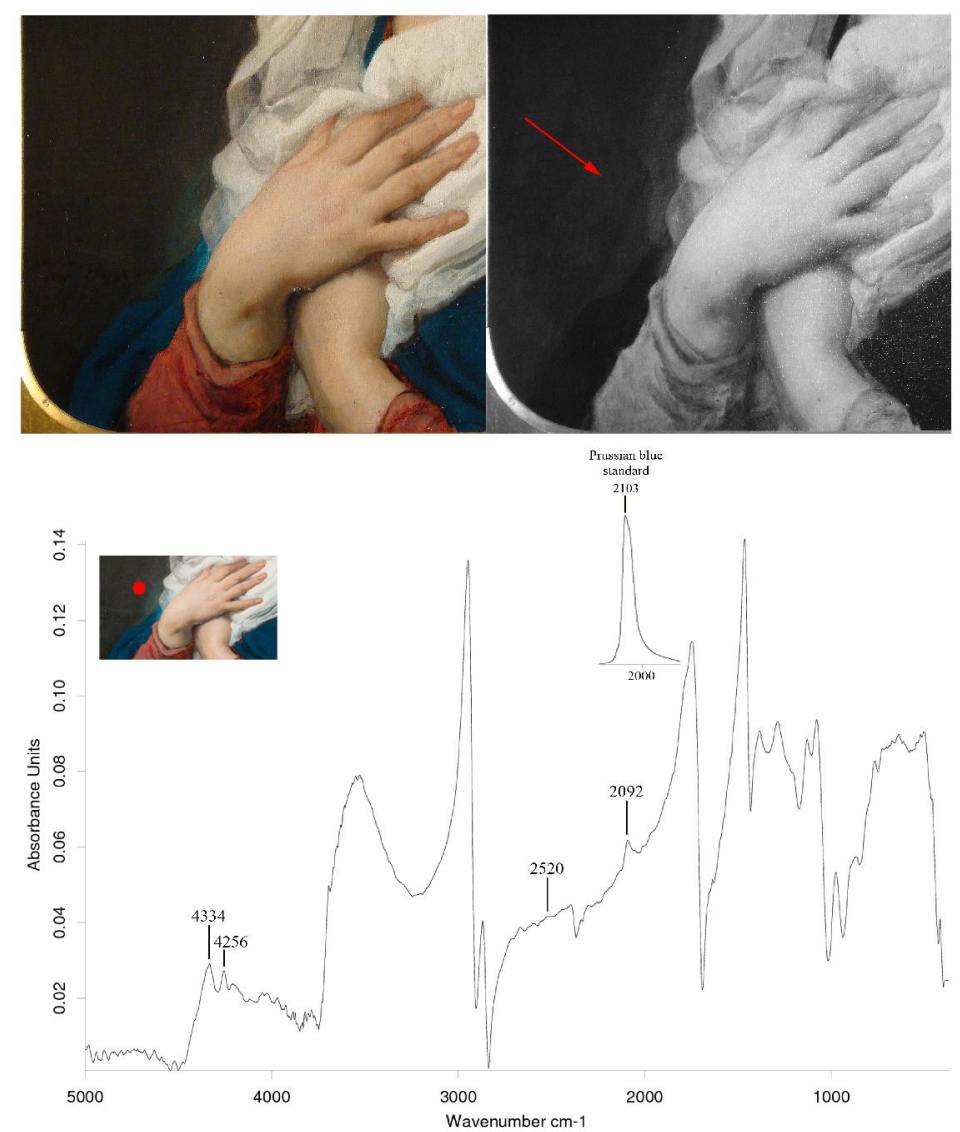

Figure 6 Picture under light (top left) and infrared image (top right) of a detail of Madonna (Galleria dell'Accademia Tadini). The pentimento is marked by an arrow. FTIR spectrum in pseudo-absorbance (bottom) of the retouching, showing the peculiar peaks of Prussian blue $\left(2092 \mathrm{~cm}^{-1}\right)$, white lead $\left(2520 \mathrm{~cm}^{-1}\right)$ and of a siccative oil $\left(4334,4256 \mathrm{~cm}^{-1}\right)$. The peculiar peak of Prussian blue reference is also shown. 
In a few blue areas, for example in Pietro l'Eremita and I Vespri Siciliani, cobalt blue was revealed $\left(\mathrm{CoAl}_{2} \mathrm{O}_{4}\right.$, created by Leithner in 1775), due to the absorbance band at around 665 and the sub-bands at 6610 and $7230 \mathrm{~cm}^{-1}$ [Miliani 2007 , Vetter 2011]. We are not completely sure about the interpretation, as the noise in this zone of the spectra prevents a reliable identification (Figure 7). FTIR analyses carried out on the light blue and violet sky of the dawn behind Ecce Homo and on the blue mantel of L'angelo annunziatore revealed (Figure 8) a signal around $2340 \mathrm{~cm}^{-1}$, which is diagnostic of natural ultramarine, a sodium, aluminum and sulfur silicate [Derrick 1999]. In particular, it corresponds to $\mathrm{CO}_{2}$ trapped inside the mineral during its formation [Miliani 2008]. In some paintings, these blue pigments are mixed with ochres, in order to get opaque and less transparent hues.

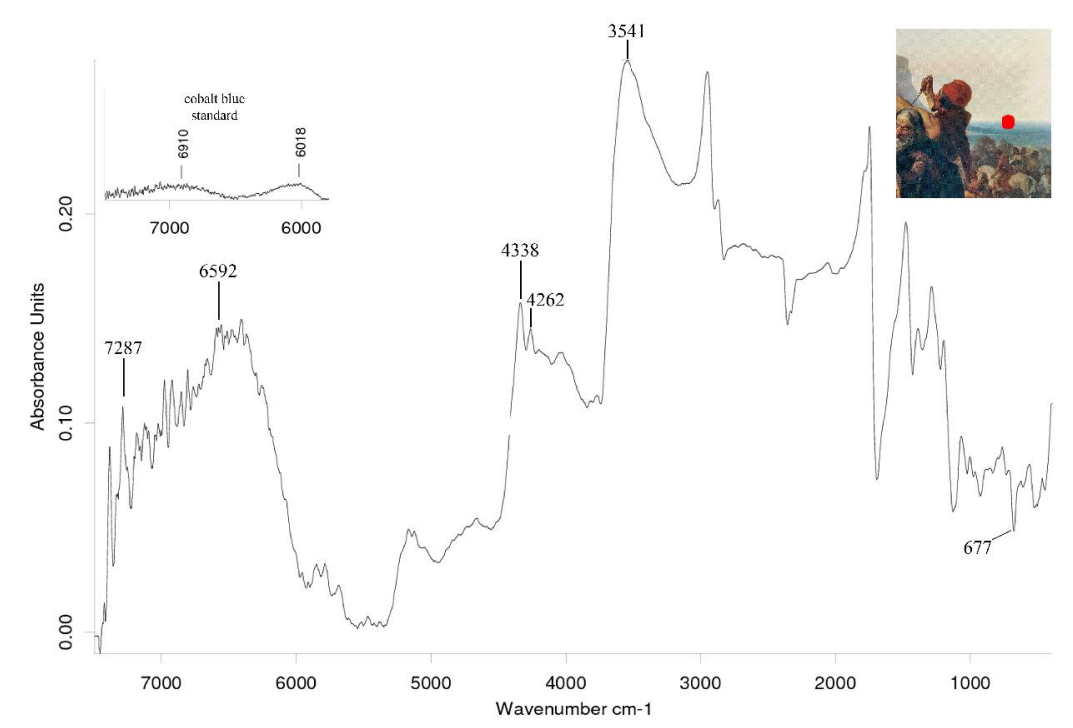

Figure 7 FTIR spectrum in pseudo-absorbance of blue area of I Vespri Siciliani (Galleria Nazionale d'Arte Moderna e Contemporanea), suggests the presence of cobalt blue $\left(7287,6592,677 \mathrm{~cm}^{-1}\right)$, of a siccative oil $\left(4338,4262 \mathrm{~cm}^{-1}\right)$ and white lead $\left(3541 \mathrm{~cm}^{-1}\right)$. The peculiar peaks of cobalt blue reference are also shown.

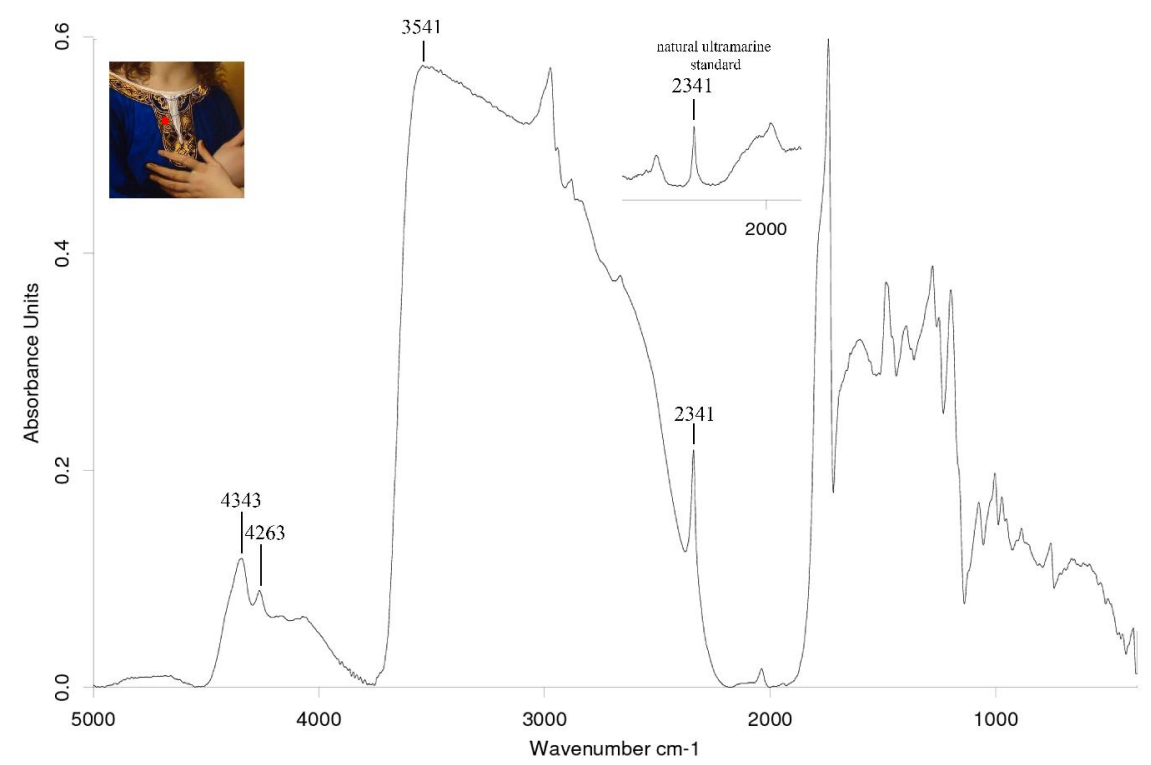

Figure 8 FTIR spectrum in pseudo-absorbance of a blue area of Angelo Annunziatore (private Collection), suggesting the presence of natural ultramarine $\left(2341 \mathrm{~cm}^{-1}\right)$, white lead $\left(3541 \mathrm{~cm}^{-1}\right)$ and a siccative oil $\left(4344,4263 \mathrm{~cm}^{-1}\right)$. The peculiar peak of natural ultramarine reference is also shown. 
Red pigments. The earthy red hue and the rose area analyzed in La ciociara and in L'incontro di Giacobbe ed Esaù, respectively, produced spectra with a signal at $3695 \mathrm{~cm}^{-1}$, as a weak but well resolved peak, which is the stretching of the O-H group of kaolinite, $\mathrm{Al}_{2} \mathrm{Si}_{2} \mathrm{O}_{5}(\mathrm{OH})_{4}$, a mineral always associated with ochres [Wilson 1994, Eastaugh 2008, Vetter 2011, Miliani 2012]. The same signal was observed in the Madonna (Figure 9). Further Si-O modes were not distinguished from the matrix signals.

Signals at around $630-680 \mathrm{~cm}^{-1}$ of the clay minerals normally present in cinnabar as impurities were present in the spectra recorded only in some red areas (Figure 9) [Wilson 1994, Eastaugh 2008, Miguel 2014, Franquelo 2016]. The presence of minerals associated with the main component, whose signals fell outside the range measured with a portable FTIR instrument (below $300 \mathrm{~cm}^{-1}$ ), may be only indicative and cannot absolutely lead to an unambiguous determination. In just one case, a red area of I Vespri Siciliani, the weak peak at $380 \mathrm{~cm}^{-1}$ suggested the presence of minium, however the position at the edge of the instrumental working region, affected by noise, prevented a reliable identification [Vahur 2009].

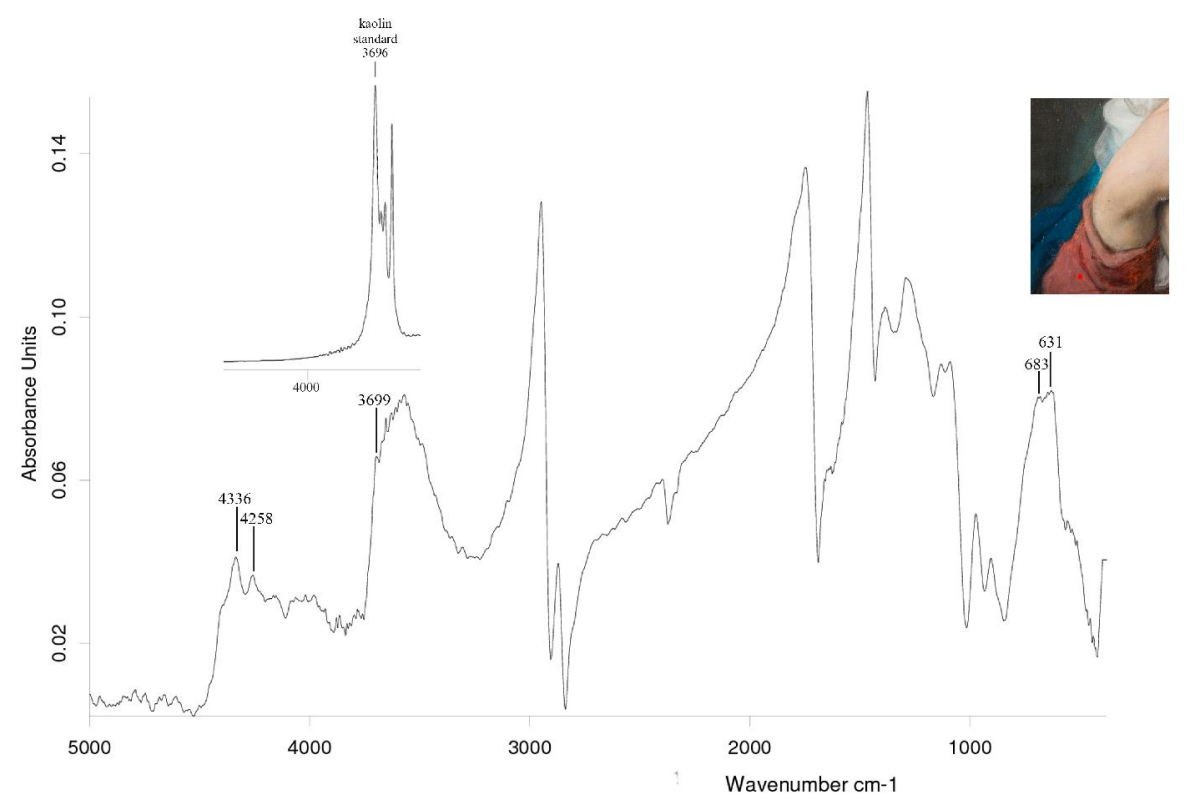

Figure 9 FTIR spectrum in pseudo-absorbance of a red area of Madonna (Galleria dell'Accademia Tadini), suggesting the presence of kaolinite (3699 $\left.\mathrm{cm}^{-1}\right)$ and of a siccative oil $\left(4336\right.$ and $\left.4258 \mathrm{~cm}^{-1}\right)$. The peaks at 683 and $631 \mathrm{~cm}^{-1}$ could be associated with clay minerals present in cinnabar as impurities. The peculiar peak of kaolin reference is also shown

Rosy pigments. The analyses of the skin on the faces, arms and hands led to the identification of the peak at $3695 \mathrm{~cm}^{-1}$, usually as sharp-shaped, which is the stretching of the $\mathrm{O}-\mathrm{H}$ group of kaolinite, $\mathrm{Al}_{2} \mathrm{Si}_{2} \mathrm{O}_{5}(\mathrm{OH})_{4}$, a mineral normally present in red and yellow ochres [Wilson 1994, Eastaugh 2008, Vetter 2011, Miliani 2012]. The colour was obtained by Francesco Hayez by adding ochres to white lead.

White. White lead was ubiquitous, as already discussed. In five paintings, the peaks around 1965, 2064, 2132, 2190 and $2335 \mathrm{~cm}^{-1}$ were clearly visible, for example in Ritratto del nobile Giulio Vigoni bambino (Figure 10). The particular pattern of combination recalls that of the stretching bands of barite $\left(\mathrm{BaSO}_{4}\right)$ sulfate ion [Miliani 2012]. Barite is known to have been used for financial reasons since the $18^{\text {th }}$ century given that it is an inert extender of white lead, which dilutes the pigment and thus reduces the cost [Artists' Pigments 1997].

Yellow pigments. Basing upon the peak at around $678 \mathrm{~cm}^{-1}$, Hayez appears to have used Naples yellow, i.e. lead antimonate $\mathrm{Pb}_{3}\left(\mathrm{SbO}_{4}\right)_{2}$, in both I due apostoli Giacomo e Filippo and Pietro l'Eremita [Vetter 2011]. The band could 
interfere with that of white lead (bending vibration), however the broader shape of the band, and the much less intensity of the absorbance observed in white areas containing only white lead, point towards the identification with Naples yellow. The pigment was used in ancient times and recovered in the 18th century.

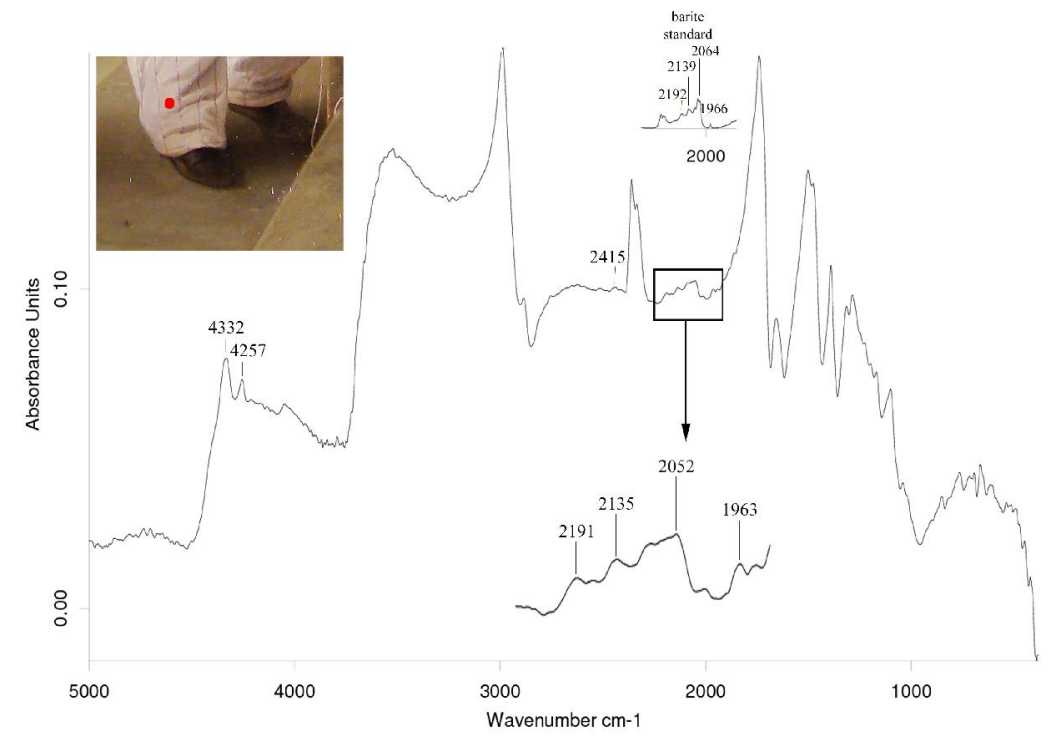

Figure 10 FTIR spectrum in pseudo-absorbance of a white area of Ritratto del nobile Giulio Vigoni bambino (Villa Vigoni), suggesting the presence of barite $\left(2191,2135,2052\right.$ and $\left.1963 \mathrm{~cm}^{-1}\right)$, of a siccative oil $\left(4332\right.$ and $\left.4257 \mathrm{~cm}^{-1}\right)$ and of white lead $\left(2415 \mathrm{~cm}^{-1}\right)$. The peculiar peaks of barite reference are also shown.

Figure 11 shows the spectrum of this pigment in Pietro l'Eremita, where the feature appears as an inverted peak (Reststrahlen band). The spectrum recorded on a golden area of the same painting shows a completely different set of bands. The peaks around 580, 494 and $423 \mathrm{~cm}^{-1}$ match with the reference of lead-tin yellow type I (lead stannate, $\mathrm{Pb}_{2} \mathrm{SnO}_{4}$ ), also called giallorino and first cited by Cennino Cennini (Figure 11). The bands are ascribable to Sn-O and $\mathrm{Pb}-\mathrm{O}$ vibrations respectively [Artists' Pigments 1997]. The natural earthy shades analyzed in La ciociara and L'incontro di Giacobbe ed Esaù and the yellow areas of I Vespri Siciliani and again L'incontro di Giacobbe ed Esaù revealed a shoulder or weak peak at $3695 \mathrm{~cm}^{-1}$, which is in agreement with the stretching of O-H group of kaolinite, $\mathrm{Al}_{2} \mathrm{Si}_{2} \mathrm{O}_{5}(\mathrm{OH})_{4}$, a mineral associated with ochres [Wilson 1994, Eastaugh 2008, Vetter 2011, Miliani 2012].

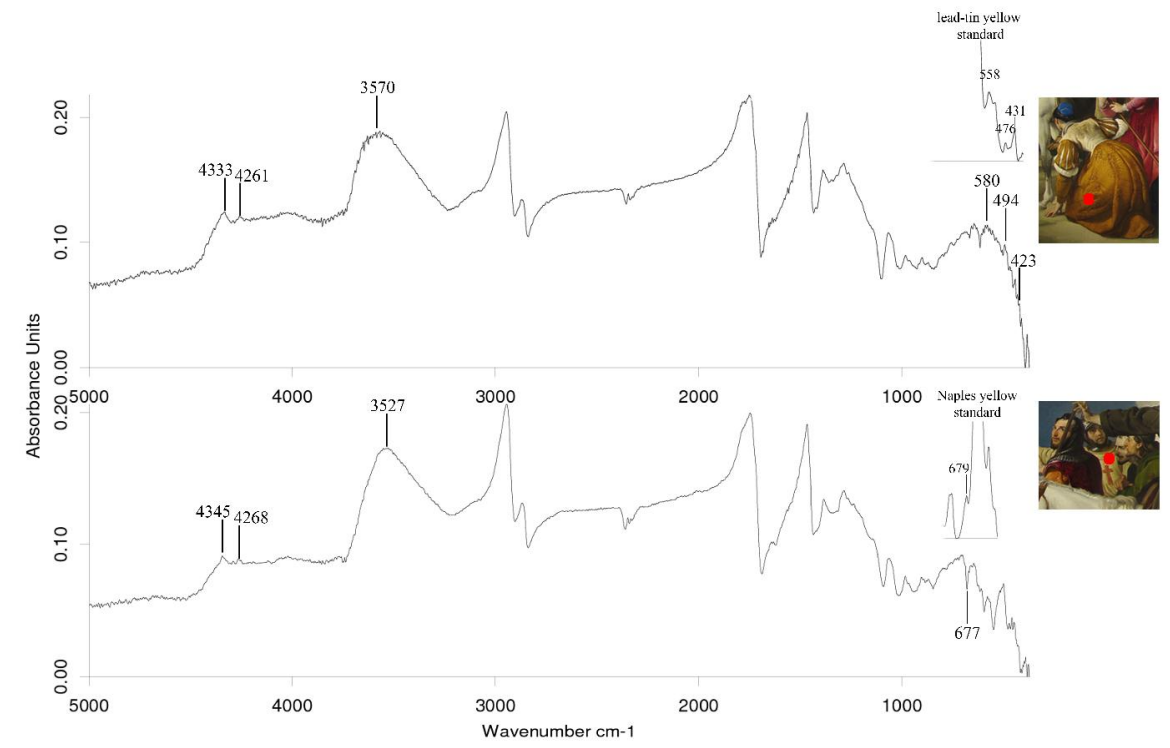

Figure 11 FTIR spectra in pseudo-absorbance of two yellow areas in Pietro l'Eremita (private collection). The marked peaks refer to lead-tin yellow (580, 494 and $\left.423 \mathrm{~cm}^{-1}\right)$, a siccative oil (4333 and $\left.4261 \mathrm{~cm}^{-1}\right)$ and white lead $\left(3570 \mathrm{~cm}^{-1}\right)$ (top). Naples yellow (677 $\left.\mathrm{cm}^{-1}\right)$, a siccative oil $(4345$ and $\left.4268 \mathrm{~cm}^{-1}\right)$ and white lead $\left(3527 \mathrm{~cm}^{-1}\right)$ are present in the spectrum at the bottom. The peculiar peaks of lead-tin yellow and Naples yellow references are also shown. 
Green pigments. Just three easel paintings contained green areas. The diagnostic peaks at around 2090 and $678 \mathrm{~cm}^{-1}$, pointed to a mixture of Prussian blue with Naples yellow, respectively.

Preparation. As concerns the ground layer, one painting (Ritratto di Giulio Mylius, oil on canvas), was under restoration and without a frame. The preparation exposed on one side of the canvas was analyzed. The aforementioned set of particular FTIR peaks identified white lead and a siccative oil, possibly linseed oil (Figure 12). The sharp peaks at 1689 and $1622 \mathrm{~cm}^{-1}$ and at around $1120 \mathrm{~cm}^{-1}$ are the characteristic bending vibrations and the stretching mode of gypsum, respectively [Mandal 2002, Derrick 1999].

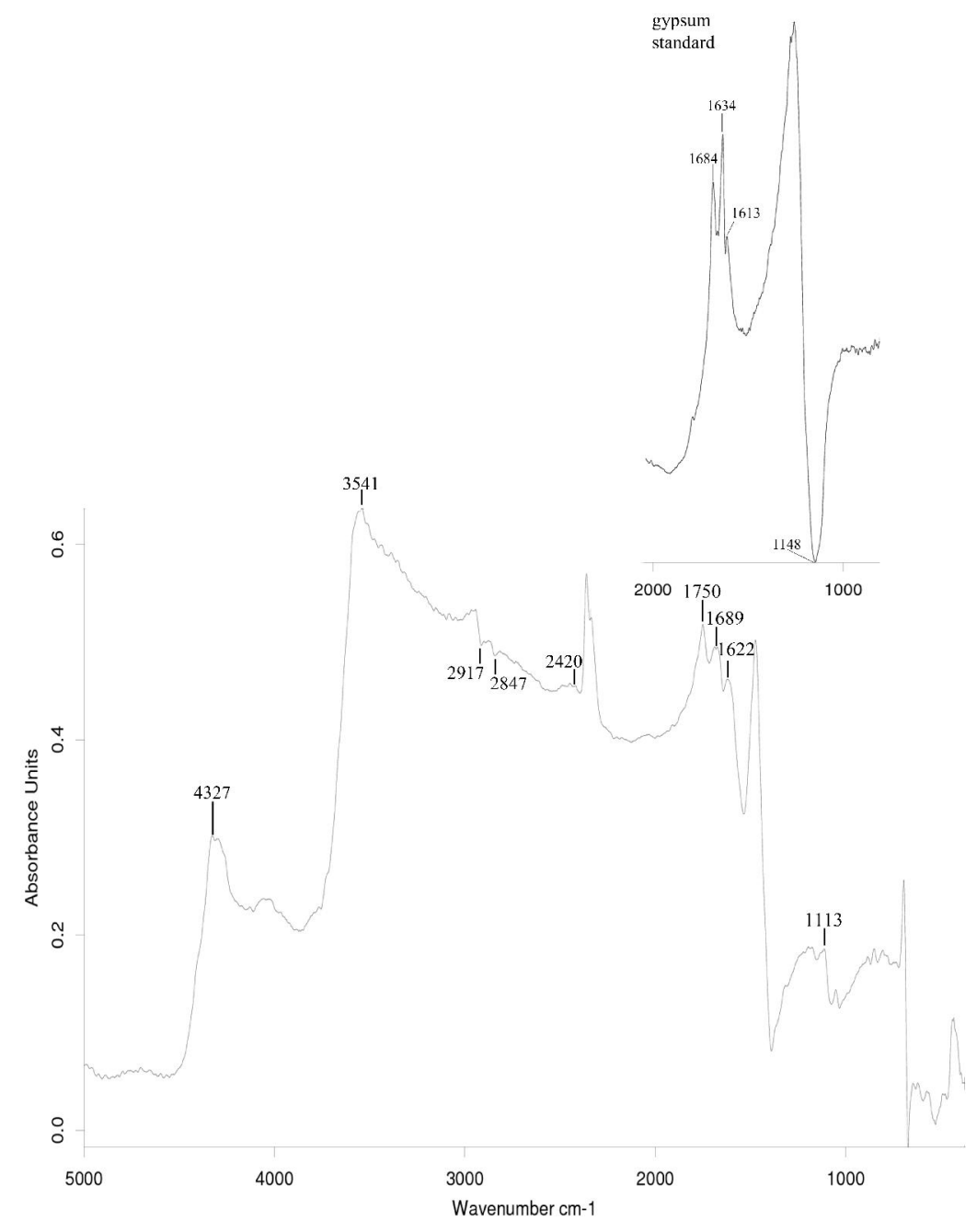

Figure 12 FTIR spectrum in pseudo-absorbance of the ground layer of Ritratto di Giulio Mylius (Villa Vigoni), suggesting the presence of white lead $\left(3541,2420,1750 \mathrm{~cm}^{-1}\right)$, siccative oil $\left(4327,2917,2847,1750 \mathrm{~cm}^{-1}\right)$ and gypsum $\left(1689,1622,1113 \mathrm{~cm}^{-1}\right)$. The peculiar peaks of gypsum reference are also shown.

The peculiar peaks previously discussed, showed that in some zones ivory black is mixed with Prussian blue, obtaining particular "cold" black hues, or with lead white to obtain brown and grey colours. Ivory black was also identified in red and yellow areas, where Hayez painted shadow effects with a black pigment. In general terms, the quality of the spectra was satisfactory and the bands were well resolved, depending on the surface morphology and on the pigmented areas investigated, and a comparison with the database of reference pigments was possible. The intense peaks of the siccative oil and white lead represent most of the signals in all the spectra, making the identification of other compounds rather difficult and limited to one or a few particular peaks of specific functional groups. The relative intensity of their particular bands is constant in each easel painting, suggesting that the two compounds are related. 


\section{Infrared Reflectography}

The imaging analysis led to the identification of various underdrawings and pentimenti carried out during the painting process, and some areas that had been restored. The most noteworthy example was L'ultimo bacio dato a Giulietta da Romeo, where the profile of Juliet had been altered during the painting process. Francesco Hayez apparently decided to position the faces of two lovers closer one to the other, while he was painting the scene (Figure 13). In some zones the lines of the sketch regarding Romeo's and Juliet's face design can also be seen. In the same painting a change made to the size of Romeo's left foot is visible together with pentimenti in the pattern of the coloured window frames and in the height of the architecture in the background.

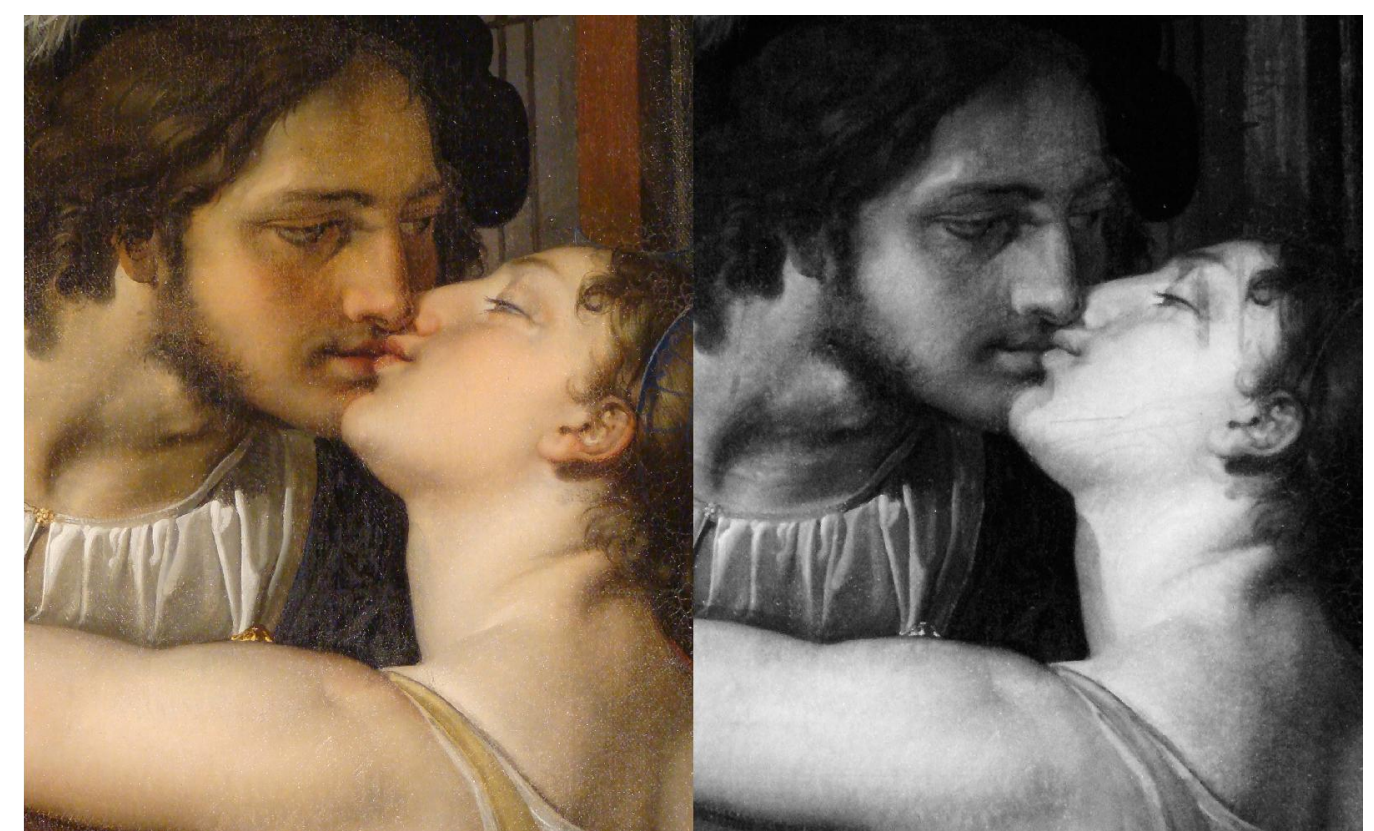

Figure 13 Photograph under light (left) and respective IRR image (right) of a detail from L'ultimo bacio dato a Giulietta da Romeo (Villa Carlotta), which shows the pentimento concerning Juliet's profile.

In L'incontro di Giacobbe ed Esaù Francesco Hayez had planned on including a larger number of people in the background to the main characters, making the scene more dramatic. While executing the composition, the painter decided on a simpler final version, and now we can see only shadows among the profiles in the background in the IRR images (Figure 14).

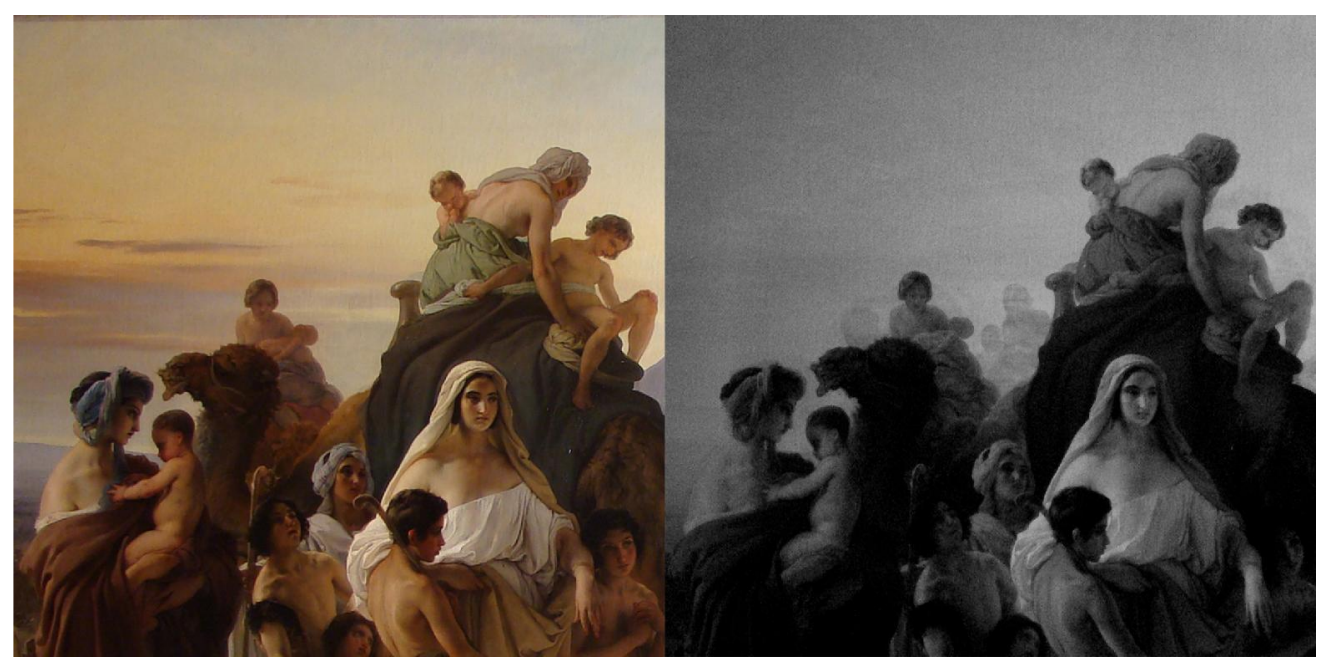

Figure 14 Photograph under light (left) and respective IRR image (right) of a detail from L'incontro di Giacobbe ed Esaù (Musei Civici di Arte e Storia, Brescia), which shows the pentimento concerning the profiles in the background. 
Underdrawings were identified in some of the paintings, such as under the hands and feet in I due apostoli Giacomo $e$ Filippo and L'angelo annunziatore, or under the face of Luigia and Giulio in Ritratto di Luigia Vitali Mylius Vigoni and Ritratto di Giulio Mylius, respectively, or in the background of I profughi di Parga. Because the drawing is visible in the infrared, Francesco Hayez would appear to have used a carbonaceous material or an infrared opaque material. Why the reflectograms did not also identify drawings, could be related either to the absence of any drawing or to the use of a non-carbon based material or an infrared transparent material. The underdrawings revealed in this project are different. In I due apostoli Giacomo e Filippo the lines of the sketch are more marked, energetic and vigorous, as clearly visible in Figure 15, while in the other paintings mentioned above, the lines are lighter. In the sketch visible under the Ritratto di Luigia Vitali Mylius Vigoni, the underdrawing seems more controlled, and traces the contours of the facial details [Valadas 2016, Cardeira 2016, Carini 2013].

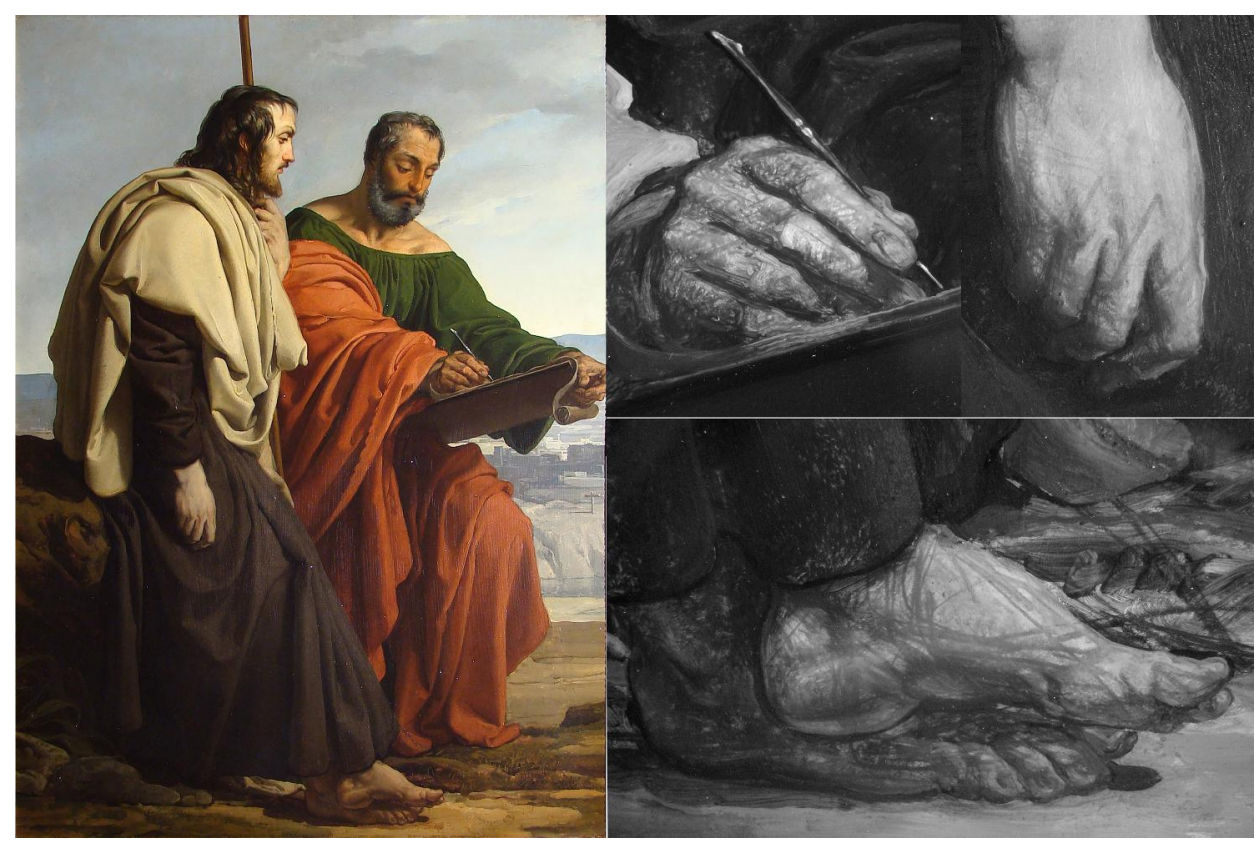

Figure 15 Photograph under light (left) and respective IRR image (right) of details from I due apostoli Giacomo e Filippo (private collection). The vigorous underdrawings are evident.

The reflectography and infrared in false colour (IRFC) revealed past restoration works: in fact several pigments responded differently due to the fact that they had different compositions. An example is clearly visible in Madonna, which revealed a retouching of the blue mantle. Figure 16 highlights the pink retouching surrounded by a dark colour belonging to the original pigment [Bersani 2015].

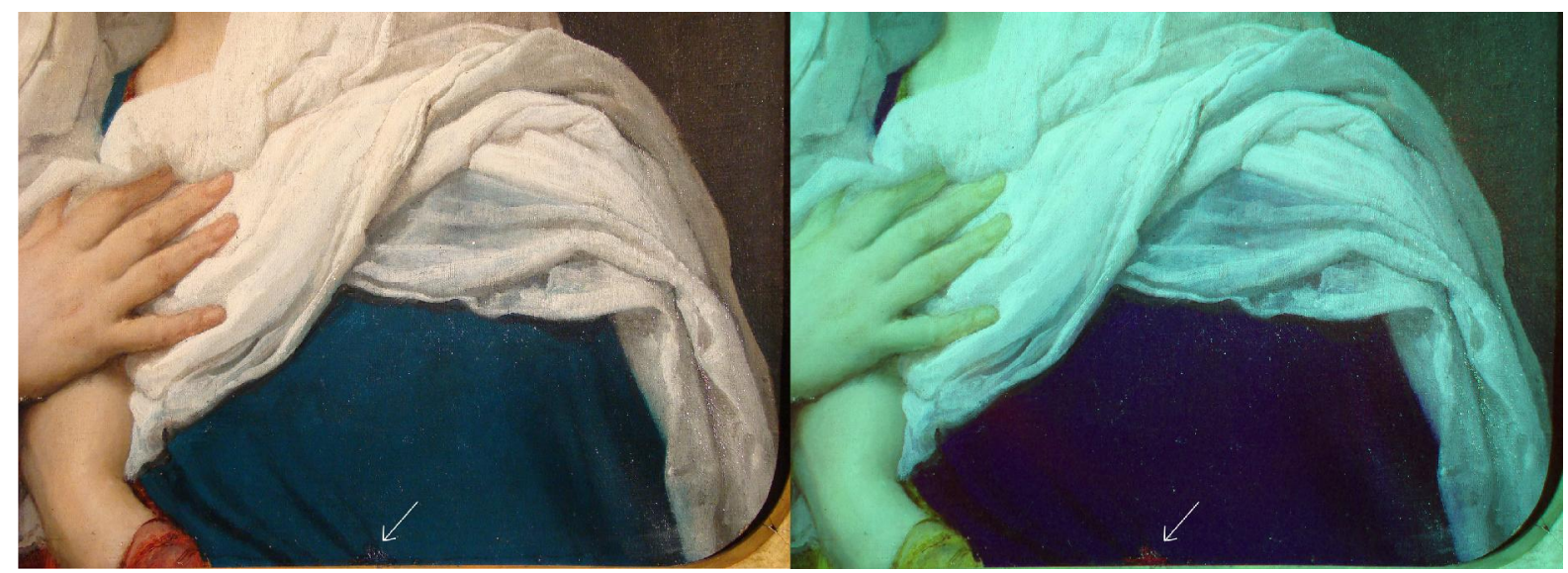

Figure 16 Picture under light (left) and false colour image (right) of a restored area in Madonna (Galleria dell'Accademia Tadini). The restored area is marked by an arrow. 


\section{Conclusions}

This non-invasive study provides the first systematic investigation into Hayez's palette, thereby contributing to the knowledge of his painting technique and indirectly by providing insights into the extent to which his technique matched the techniques typical of his era.

Imaging investigations revealed that Francesco Hayez used to retouch the compositions as he went along, worrying about the details right to the end of the realization of his paintings. In general terms, we see few signs of hesitation in the layout of the compositions, thus revealing a confident draughtsmanship. The preliminary drawing is almost absent, suggesting a great freedom of execution and masterful handling of the brush. The painting method also tells us about his personality. For example, the retouching of Juliet's profile is significant, as he put Romeo and Juliet closer to each other, ignoring any potential criticism of the sensual gesture.

Regarding Hayez's materials, we found direct evidence of the use of some pigments and drew hypotheses regarding others. The results are in line with the few data in the literature on the Hayez palette, although obtained with other techniques, revealing a typical traditional palette and ground, with a liberal use of costly pigments, which lead to brilliant colours with long-term stability [Perusini 2010, Princivalle 2010, Carini 2013]. The ground mixture is similar to that identified in other paintings of Hayez, where a sampling of the layer was possible [Ferriani 2009]. In addition, we were able to identify the organic fraction in the ground and painting layer, namely a siccative oil, and ascertained the presence of barite and lead-tin yellow. The hypothesis on the kind of oil is partly due to the signals, but mostly to the documents on the availability of this oil at the time. In 1821 the first edition of the "Il libro dell'arte" by Cennino Cennini was printed and linseed oil was widely recommended among the artists' community [Bensi 1993]. The possible use of cobalt blue, for example for the cap of central female figure in Pietro l'Eremita, suggests that Hayez had tested this new color - which had been available in Milan since the second decade of 19th century - in small areas in order to replace the very expensive deep blue of natural ultramarine. The pigments were often blended to obtain grey and brown hues or a "cold" appearance, in the dark blue and black zones.

Egg white (glair) varnishes have been used since the days of Cennino Cennini and chiefly as temporary varnishes, which were intended to be removed when a painting had dried enough to apply a final varnish [Swicklik 1993]. On 1 August 1841 Teresa Borri wrote about the portrait of her husband, the famous writer Alessandro Manzoni: "Ad Hayez ho detto che gli lascio il ritratto fino al nostro ritorno di Lesa [...] Quanto alla vernice lo Stefano ed io non vogliamo lasciarla dare se non tra due anni, perché non ingiallisca, né annerisca, intanto un po' di chiara d'uovo, o anche niente, come Hayez crederà" ("I told Hayez that I would leave him the portrait until we came back from Lesa [...] Regarding the varnish, Stefano and I would prefer it not to be applied for the next two years, in order to avoid yellowing or blackening, so for the moment just a little egg white or nothing at all, as Hayez sees fit") [Flori 1938]. As concerns the presence of resins, these could be ascribed to a glazing applied by Hayez to the paintings, in order to obtain more transparent hues. The painter used this practice, as described in ancient treatises [Armenini 1578]. On the contrary, resins could originate from conservation practices, which since the end of $19^{\text {th }}$ century recommended the use of reversible varnish colours [Cavenaghi 1912].

Our results show that Hayez's working method consisted in layering colours mixed with significant amounts of white lead, thus giving homogeneous, more resistant, hard, transparent films. As a secondary effect, the dilution of pigments with white lead achieved the desired nuance.

This study confirmed the key role of reflection FTIR spectroscopy as a method for painting analysis, demonstrating that portable devices are viable alternatives to laboratory-based analytical techniques, especially for artworks which cannot 
be moved and where sampling is not possible. Various drawbacks of portable FTIR spectroscopy were encountered, which did not unambiguously identify the red pigments, except for red ochre. Consequently, the use of another noninvasive analytical method is advisable.

Our results could be of great interest for conservators, in order to plan the best conservation works, which are as similar and compatible as possible to the original composition, and for art historians.

\section{Acknowledgments}

The authors gratefully acknowledge the Lombardy Region and the European Union for funding the project "The palette of Francesco Hayez" (POR Lombardia Ob. 2 FSE 2007/2013), the private art collectors and the museums who gave permission for the analyses of the paintings: Galleria Tadini (Lovere, BG, Italy), Villa Carlotta (Tremezzo, CO, Italy), Villa Vigoni (Menaggio, CO, Italy), Musei Civici d'Arte e di Storia (Brescia, Italy), Galleria Civica d'Arte Moderna e Contemporanea (Torino, Italy), Galleria Nazionale d'Arte Moderna e Contemporanea (Roma, Italy), Galleria d'Italia (Milan). The authors would also like to thank the restorers, Paolo Aquilini and Carlotta Beccaria for their helpful discussion of the results. Valentina Brunello, Cristina Corti and Elena Lissoni gratefully acknowledge Università degli Studi dell'Insubria and regional government of Lombardy for funding their research grants

\section{References}

AA.VV. Artists' Pigments: volume 1, Feller R.L. (Ed.), Oxford University Press, London, 1985; volume 2, Roy A. (Ed.), Oxford University Press, London, 1993 volume 3, Fitzhugh E.W. (Ed.), Oxford University Press, London, 1997. Armenini G.B., De' veri precetti della pittura, Ravenna 1578.

Bensi P., L' inventario della bottega di colori di Angelo Mattei in Roma (1847), Arte documento 7, (1993) $255-258$.

Bensi P., La tecnica pittorica nei dipinti su tela di Francesco Hayez, in Le tecniche pittoriche dell'Ottocento in Friuli e a Trieste, 2010 Forum Udine.

Bersani D., Berzioli M., Caglio S., Casoli A., Lottici P. P., Medeghini L., Poldi G., Zannini P.. An integrated multianalytical approach to the study of the dome wall paintings by Correggio in Parma cathedral, Microchemical Journal 114 (2014) 80-88.

Cardeira A.M., Longelin S., Costa S., Candeias A., Carvalho M.L., Manso M., Analytical characterization of academic nude paintings by José Veloso Salgado, Spectrochimica Acta Part A 153 (2016) 379-385.

Carini A., Marelli I., Poldi G., L’Odalisca di Francesco Hayez, Kermes 91 (2013) 40-46.

Carlyle L., Paint driers discussed in 19th-century British oil painting manuals, JAIC 38 (1999) 69-82.

Cavenaghi L., Il restauro e la conservazione dei dipinti. Conferenza di Luigi Cavenaghi, in Italia, Atti del I Convegno degli ispettori onorari dei monumenti e scavi, Roma (1912) 488-500. 
de Viguerie L., Payard P.A., Portero E., Walter Ph., Cotte M., The drying of linseed oil investigated by Fourier transform infrared, Progress in Organic Coatings 93 (2016) 46-60.

Derrick M.R., Stulik D., Landry J.M., Infrared Spectroscopy in Conservation Science, Getty Conservation Institute 1999.

Di Majo E., Pagliani E., I Vespri siciliani di Francesco Hayez (Galleria Nazionale d'Arte Moderna di Roma). Restauro e indagini sulla tecnica, Kermes 7 (1990) 10-19.

Eastaugh N., Walsh V., Chaplin T., Siddall R., Pigment compendium. A dictionary and optical microscopy of historical pigments, 2008, Butterworth-Heinemann, Oxford.

Ferriani B., Perazzolli C., Mattarelli M., Montagna M., Gialanella S., Francesco Hayez: alcune considerazioni sulle preparazioni, sulla tecnica e sulla conservazione, in Effetto luce. Materiali, tecnica, conservazione della pittura italiana dell'Ottocento, 2009, Edifir Firenze, 75-90.

Flori E., Il figliastro del Manzoni, Stefano Stampa, 1938, Istituto Editoriale Cisalpino, Milano, page 79.

Franquelo M. L., Perez-Rodriguez J. L., A new approach to the determination of the synthetic or natural origin of red pigments through spectroscopic analysis, Spectrochimica Acta Part A 166 (2016) 103-111.

Gargano M., Ludwig N., G. Poldi G., A new methodology for comparing IR reflectographic systems, Infrared Physics and Technology 49 (2007) 249-253.

Gettens R.J., Stout G.L., Painting materials. A short Encyclopaedia, 1966, Dover Publications, New York.

Madariaga J.M., Maguregui M., Castro K., Knuutinen U., Martı'nez-Arkarazo I., Portable Raman, DRIFTS, and XRF analysis to diagnose the conservation state of two wall painting panels from Pompeii deposited in the Naples National Archaeological Museum (Italy), Applied Spectroscopy 70 (2016) 137-146.

Mandal P.K., Mandal T.K., Anion water in gypsum $\left(\mathrm{CaSO}_{4} 2 \mathrm{H}_{2} \mathrm{O}\right)$ and hemihydrate $\left(\mathrm{CaSO}_{4} 1 / 2 \mathrm{H}_{2} \mathrm{O}\right)$, Cement and Concrete Research 32 (2002) $313-316$.

Manfredi M., Barberis E., Rava A., Robotti E., Gosetti F., Marengo E., Portable diffuse reflectance infrared Fourier transform (DRIFT) technique for the non-invasive identification of canvas ground: IR spectra reference collection, Analytical methods 7 (2015) 2313-2322.

Mazzocca F. (edited by), Francesco Hayez, catalogue of the exhibition held at Gallerie d'Italia Milano, november 2015 february 2016), Cinisello Balsamo (Milano) 2015.

Meilunas R., Bentsen J., Steinberg A., Analysis of aged paint binders by FTIR spectroscopy, Studies in Conservation 35 (1990) 33-51. 
Miguel C., V. Pinto J., Clarke M., Melo M. J., The alchemy of red mercury sulphide: The production of vermilion for medieval art, Dyes and Pigments 102 (2014) 210-217.

Miliani C., Rosi F., Burnstock A., Brunetti B.G., Sgamellotti A., Non-invasive in situ investigations versus microsampling: a comparative study on a Renoirs painting, Applied Physics A 89 (2007) 849-856.

Miliani C., Daveri A., Brunetti B.G., Sgamellotti A., $\mathrm{CO}_{2}$ entrapment in natural ultramarine blue, Chemical Physics Letters 466 (2008) 148-151.

Miliani C., Rosi F., Daveri A., Brunetti B.G., Reflection spectroscopy for the non-invasive in situ study of artists' pigments, Applied Physics A 106 (2012) 295-307.

Moon T., Schilling M. R., Thirkettle S., A Note on the Use of False-Color Infrared Photography in Conservation, Studies in Conservation 37 (1992) 42-52.

Perusini G., Le tecniche pittoriche e la formazione artistica a metà Ottocento nelle Accademie di Venezia e Vienna, in Le tecniche pittoriche dell'Ottocento in Friuli e a Trieste, 2010 Forum Udine, 11-40.

Poldi G., Villa G.C.F., Dalla Conservazione Alla Storia Dell'arte, Riflettografia e Analisi Non Invasive per lo studio dei dipinti, Edizioni della Normale, Pisa, 2006.

Princivalle A., Indagini scientifiche su dipinti dell'Ottocento triestino, in Le tecniche pittoriche dell'Ottocento in Friuli e a Trieste, 2010 Forum Udine, 105-109.

Ren F., Ding Y., Leng Y., Infrared spectroscopic characterization of carbonated apatite: A combined experimental and computational study, Journal of Biomedical Materials Research A, 102A (2014) 496-505.

Rifkin R. F., Prinsloo L. C., Dayet L., Haaland M. M., Henshilwood C. S., Lozano Diz E., Moyo S., Vogelsang R., Kambombo F., Characterising pigments on 30 000-year-old portable art from Apollo 11 Cave, Karas Region, southern Namibia, Journal of Archaeological Science Reports 5 (2016) 336-347.

Rosi F., Daveri A., Moretti P., Brunetti B.G., Miliani C., Interpretation of mid and near-infrared reflection properties of synthetic polymer paints for the non-invasive assessment of binding media in twentieth-century pictorial artworks, Microchemical Journal 124 (2016) 898-908.

Sessa C., Bagán H., García J.F., Influence of composition and roughness on the pigment mapping of paintings using mid-infrared fiberoptics reflectance spectroscopy (mid-IR FORS) and multivariate calibration, Analytical and Bioanalytical Chemistry 406 (2014) 6735-6747.

Swicklik M., French painting and the use of varnish, 1750-1900, in Conservation research, Studies in the history of art, 41 (1993), Monograph series 2, National Gallery of Art Washington, 157-74. 
Tomasini E., Siracusano G., Maier M.S., Spectroscopic, morphological and chemical characterization of historic pigments based on carbon. Paths for the identification of an artistic pigment, Microchemical Journal 102 (2012) 28-37.

Vagnini M., Miliani C., Cartechini L., Rocchi P., Brunetti B.G., Sgamellotti A., FT-NIR spectroscopy for non-invasive identification of natural polymers and resins in easel paintings, Analytical and Bioanalalytical Chemistry 395 (2009) $2107-2118$.

Vahur S., Knuutinen U., Leito I., ATR-FT-IR spectroscopy in the region of $500-230 \mathrm{~cm}^{-1}$ for identification of inorganic red pigments, Spectrochimica Acta Part A 73 (2009) 764-771.

Valadas S., Freire R., Cardoso A., Mirão J., Vandenabeele P., Caetano J.O., Candeias A., New insight on the underdrawing of 16th Flemish-Portuguese easel paintings by combined surface analysis and micro analytical techniques, Micron 85 (2016) 15-25.

Van Strydonck M., Decq L., Van den Brande T., Boudin M., Ramis D., Borms H., G. De Mulder, The protohistoric 'quicklime burials' from the Balearic Islands: cremation or inhumation, International Journal of Osteoarchaeology 25 (2015) 392-400.

Vetter W., Schreiner M., Characterization of pigment-binding media systems - Comparison of non-invasive in-situ reflection FTIR with transmission FTIR microscopy, e-Preservation Science 8 (2011) 10-22.

Wilson, M.J., Clay mineralogy: spectroscopic and chemical determinative methods, 1994, Chapman\&Hall, London. 